Published in final edited form as:

Cryobiology. 2014 June ; 68(3): 419-430. doi:10.1016/j.cryobiol.2014.03.005.

\title{
Survivals of mouse oocytes approach $100 \%$ after vitrification in 3-fold diluted media and ultra-rapid warming by an IR laser pulse
}

\author{
Bo Jin ${ }^{\mathrm{a}}$, F.W. Kleinhans ${ }^{\mathrm{a}, \mathrm{b}}$, and Peter Mazura, ${ }^{\mathrm{*}}$ \\ aFundamental and Applied Cryobiology Group, Department of Biochemistry and Cellular and \\ Molecular Biology, The University of Tennessee, Knoxville, TN 37996-0840, USA

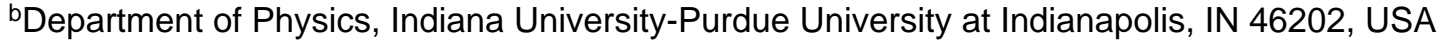

\begin{abstract}
Vitrification is the most sought after route to the cryopreservation of animal embryos and oocytes and other cells of medical, genetic, and agricultural importance. Current thinking is that successful vitrification requires that cells be suspended in and permeated by high concentrations of protective solutes and that they be cooled at very high rates to below $-100^{\circ} \mathrm{C}$. We report here that neither of these beliefs holds for mouse oocytes. Rather, we find that if mouse oocytes are suspended in media that produce considerable osmotic dehydration before vitrification and are subsequently warmed at ultra high rates $\left(10,000,000^{\circ} \mathrm{C} / \mathrm{min}\right)$ achieved by a laser pulse, nearly $100 \%$ will survive even when cooled rather slowly and when the concentration of solutes in the medium is only $1 / 3^{\text {rd }}$ of standard.
\end{abstract}

\section{Keywords}

Mouse oocytes and embryos; ultra-rapid warming; laser; dehydration; recrystallization of ice; Cryo Jig; functional survival

\footnotetext{
$\star$ This work was supported by NIH Grant R01-OD011201

(C) 2014 Elsevier Inc. All rights reserved.

*Corresponding author. Fax (865) 974-9941, pmazur@utk.edu.

Author contributions P.M. conceived the idea that ultra-rapid warming rates would permit high survivals of oocytes in diluted VS media and that a laser could be used to generate the high rates. F.W.K. and he proposed that carbon black could be used as the IR absorber, and wrote the grant proposal to the NIH. F.W.K. selected the laser, designed the Cryo Jig, calculated the energies and power required to achieve the proper warming rates, and developed and executed the finite element analyses. P.M and B.J. designed the biological experiments. B.J. was responsible for superovulation and collection of oocytes and 2-cell embryos and conducted all the experiments and the determinations of morphological and functional survivals. He and F.W.K. worked on developing the Cryo Jig procedures. P.M, with major input from F.W.K. on the laser portion, wrote this paper and served as PI on the project.

Publisher's Disclaimer: This is a PDF file of an unedited manuscript that has been accepted for publication. As a service to our customers we are providing this early version of the manuscript. The manuscript will undergo copyediting, typesetting, and review of the resulting proof before it is published in its final citable form. Please note that during the production process errors may be discovered which could affect the content, and all legal disclaimers that apply to the journal pertain.
} 


\section{Introduction}

The ability to cryobiologically preserve germplasm for decades, or even centuries, is playing a central role in assisted reproduction in women, in improving the genetic quality of livestock and marine food sources, in preserving the germplasm of endangered species, and in the maintenance of mutant and transgenic lines of mice and other mammals [20]. The successful cryopreservation of mammalian preimplantation embryos was first reported in 1972 for mice [36]. More recently, the cryopreservation of the human oocyte has become a matter of intense interest [1].

A major cause of lethal injury during cryopreservation is the formation of more than a trace amount of ice within a cell $[9,17,18]$. One route to its avoidance is vitrification. In that approach, ice formation is avoided by first suspending the cells in very high concentrations of solutes, including ones that permeate the cell, and second, cooling them at high rates to $-196^{\circ} \mathrm{C}$ in liquid nitrogen $\left(\mathrm{LN}_{2}\right)$. As a result, the water in them is presumably converted from a liquid to a glass with little or no ice formation. The approach also requires high warming rates to ensure that the system does not devitrify during warming; i.e., revert from a glass to ice.

Standard vitrification has been based on two firmly held premises. One is that avoiding ice formation in cells and obtaining high survivals demands the highest of cooling rates. Consequently, a series of devices have been developed over the past decade that achieve cooling rates of $\gg 10,000^{\circ} \mathrm{C} / \mathrm{min}$ by using very small volumes of cell suspensions. One example is the Cryotop [2,13].

The second premise in the vitrification approach is that the solution in which the cells are suspended must have a very high concentration of a mixture of non-electrolytic solutes, some of which can permeate the cell and some of which can not. We have used EAFS 10/10, a solution developed by Pedro et al. [28], where E, A, F, and S refer to ethylene glycol (EG), acetamide, Ficoll, and sucrose. The total molality (Table 1, first row) is 7.38 molal, of which 6.5 molal is permeating (EG and acetamide), and the remainder are non-permeating.

Based on our previous demonstration that a very high warming rate and not a high cooling rate was the essential element in allowing mouse oocytes to survive vitrification procedures in full strength EAFS [24,31], we hypothesized and determined that the use of very high warming rates yielded high survivals of oocytes in diluted vitrification solutions [32]; namely, the percentages of oocytes in $1 / 2 \times$ EAFS that survive cooling to $-196^{\circ} \mathrm{C}$ was as high as the percentage that survive vitrification in full-strength (1×) EAFS 10/10 provided that the warming is exceedingly rapid $\left(117,000^{\circ} \mathrm{C} / \mathrm{min}\right)$. The cooling rate was of only secondary importance. We found, however, that if the concentration of $1 \times$ EAFS was further reduced to $0.33 \times$, only $5 \%$ survived subsequent cooling to $-196^{\circ} \mathrm{C}$ and warming at $117,000^{\circ} \mathrm{C} / \mathrm{min}$.

Our laboratory had determined earlier [21,31] that when partially dehydrated mouse oocytes were warmed after having been cooled to $\leq-70^{\circ} \mathrm{C}$, they began to turn black at a temperature that depended on the rate of warming. Theory indicated and observation showed that a 10fold increase in warming rate resulted in a 5 degree rise in the initiation temperature of blackening. All our evidence pointed to the blackening being the result of the growth of 
intracellular ice crystals by recrystallization. This led directly to our hypothesizing that if we could achieve still faster warming, it might be possible to avoid ice recrystallization and killing even with EAFS concentrations reduced to below $0.5 \times$.

\section{Methods}

\section{Experimental handling of oocytes and 2-cell embryos}

Obtaining oocytes-Mature female ICR mice were induced to superovulate with intraperitoneal injections of $5 \mathrm{IU}$ of equine chorionic gonadotropin (eCG) and $5 \mathrm{IU}$ of human chorionic gonadotropin (hCG) (Sigma, St. Louis) given 48h apart. Ovulated unfertilized oocytes were collected from the ampullar portion of the oviducts $13 \mathrm{~h}$ after hCG injection and were freed from cumulus cells by suspending them in modified phosphatebuffered saline (PB1) containing $0.5 \mathrm{mg} / \mathrm{ml}$ hyaluronidase followed by washing with fresh PB1 medium.

Obtaining 2-cell embryos-Female ICR mice (8-12 weeks old) were induced to superovulate with intraperitoneal injections of $5 \mathrm{IU}$ of pregnant mare serum gonadotropin (PMSG) and human chorionic gonadotropin (hCG)(Sigma, St. Louis) given $48 \mathrm{~h}$ apart. Females were mated with mature males of the same strain. To collect 2-cell embryos, the oviducts of mated females were flushed with modified phosphate buffered saline (PB1) medium 45 hrs. after the injection of hCG. The collected embryos were washed and pooled in fresh PB1 medium in a culture dish under paraffin oil to await each suite of experiments.

Preparing the test solutions-Table 1 gives the molalities of the solutes used in this study. All the solutions were prepared on a molal basis, where molality is moles of solute $/ \mathrm{kg}$ water; i.e., the necessary moles of each solute were weighed out on an analytical balance and 100g of PB1 added. PB1 is $>99 \%$ water, so the substitution of it for water introduces less than $1 \%$ error.

\section{Achieving ultra-high warming rates via a laser}

In these previous studies. we had achieved a warming rate of $117,000^{\circ} \mathrm{C} / \mathrm{min}$ by transferring a Cryotop with 5 oocytes in a $0.1 \mu \mathrm{l}$ droplet of medium from $-196^{\circ} \mathrm{C}$ into $0.5 \mathrm{M}$ sucrose in a modified isotonic phosphate buffered saline at $23^{\circ} \mathrm{C}$. A Cryotop consists of a thin plastic blade measuring $0.7 \mathrm{~mm}$ wide, $0.1 \mathrm{~mm}$ thick, and $20 \mathrm{~mm}$ long that is inserted into a plastic handle (Fig. 1) [11]. The warming rate was measured by thermocouple.

We conceived the idea that the oocytes could be warmed perhaps $100 \times$ more rapidly by applying a powerful short duration laser pulse to the droplet on the Cryotop. A search located a laser manufactured by LaserStar Corp. that met our requirements of energy and power (Fig. 2) with one important exception; namely, it emits at $1064 \mathrm{~nm}$ in the infrared but the water-rich medium and cell contents absorb poorly at that wave-length $(\sim 3.5 \%)$. The solution to this problem proved to be the introduction of a low concentration of carbon black (India Ink) into the solution. Carbon black is a Black Body that absorbs all wave lengths. The concept was that the $\mu \mathrm{m}$-sized India Ink particles would absorb the laser IR energy and be abruptly heated. They would transfer this heat to the surrounding solution, which in turn 
would transfer it to the oocyte, Note that the India Ink particles are far too large to penetrate the zona pellucida, the non-living envelope surrounding the oocyte. Consequently, they can not come in contact with the plasma membrane, much less penetrate the cell. Moreover, ample evidence shows that the small fraction of the incident laser energy absorbed by the cells themselves is too low to cause injury [15,37],

\section{The Cryo Jig}

We cooled the oocyte samples by abruptly immersing an uninsulated Cryotop in $\mathrm{LN}_{2}$. This treatment produces a cooling rate of $69,000^{\circ} \mathrm{C} / \mathrm{min}$.[11]. The next step was to fashion a Cryo Jig that would permit the cooled Cryotop to be held in $\mathrm{LN}_{2}$ inside the chamber of the Laser apparatus until warming was initiated by the laser pulse. An annotated photograph of the Jig is shown in Fig. 3, and the procedures are detailed in the Appendix

We were striving to obtain warming rates (WR) of a million degrees per minute or higher, but knew of no way to measure these directly. The alternative was to calculate them. We began by assuming that $\mathrm{WR}=(\Delta \mathrm{T} / \Delta \mathrm{t})$. (This ignores some complexities that we discuss in the Appendix) The first step was to decide on the temperature range $(\Delta \mathrm{T})$ over which the laser pulse is to be applied. The end point is $-3.5^{\circ} \mathrm{C}$, the melting point of $0.33 \times \mathrm{EAFS}$. We take the starting point to be $-180^{\circ} \mathrm{C}$ based on our estimate of how much the sample warms in air between its removal from $\mathrm{LN}_{2}$ and the firing of the laser. The duration of the pulse needed to warm at the desired rate is $\Delta \mathrm{t}=\Delta \mathrm{T} / \mathrm{WR}$. For the desired warming rates of $7.0 \times$ $10^{5}, 3.0 \times 10^{6}$, and $1.0 \times 10^{7}{ }^{\circ} \mathrm{C} / \mathrm{min}$ from $-180^{\circ} \mathrm{C}$ to $-3.5^{\circ} \mathrm{C}$, the pulse durations needed to be $15,3.5$, and $1 \mathrm{msec}$, respectively. (The two lower rates were used only to a limited extent).

Using the stereo microscope built into the laser apparatus, BJ and FWK determined for each set of runs, whether a given laser power setting resulted in a still frozen droplet, a fully melted droplet, or a clearly heat-altered oocyte. The power required to achieve the second state was selected. In addition, a control accompanied each run. It consisted of oocytes on naked Cryotop blades transferred from $\mathrm{LN}_{2}$ to the $0.5 \mathrm{M}$ sucrose solution at $23^{\circ} \mathrm{C}$. No laser was used. As mentioned, these controls warmed at $1.2 \times 10^{5}{ }^{\circ} \mathrm{C} / \mathrm{min}$ from $-180^{\circ} \mathrm{C}$ to -3.5 ${ }^{\circ} \mathrm{C}$. Additional details on the laser pulse are given in the Appendix.

\section{Post-vitrification procedures}

The laser-accelerated warming procedures were described above. After warming, the Cryotop blade was immersed with gentle shaking in $2 \mathrm{ml}$ of $0.5 \mathrm{M}$ sucrose in PB1 in a 35 $\mathrm{mm}$ culture dish at $23^{\circ} \mathrm{C}$. The procedure to warm at $117,000^{\circ} \mathrm{C} / \mathrm{min}$ without laser assistance was identical except the laser pulse was omitted. The oocytes and 2-cell embryos were then collected and transferred to fresh $100 \mu \mathrm{l}$ droplets of the same sucrose solution for $10 \mathrm{~min}$. The purpose of the 10 minute exposure to hypertonic sucrose is to prevent injurious osmotic swelling resulting from the influx of water and consequent dilution of any cryoprotective solutes that entered the cells prior to vitrification. Actually, if the plasma membranes are intact at this point, the cells shrink during the 10-min exposure if any cryoprotectants have permeated (EG or acetamide) and are flowing out. In some experiments (e.g. Solutions 11, 
12, and 13 in Table 1, there were no permeating solutes, and in those cases, the warming solution was PB1 without any sucrose.

\section{Determination of survival of oocytes and 2-cell embryos}

We used two methods to assess survivals after treatment. One was determining membrane intactness and morphological normality by the procedures described in [23]. We use the unrestricted term "survival" for them. The second was to determine the functional survival of both oocytes and 2-cell embryos for those treatments that yielded high osmotic/ morphological survival. Two measures of functional survival were used. One was the ability of the treated oocytes to be fertilized in vitro by sperm and to develop to expanded blastocysts in culture. The other was to collect and vitrify naturally developed 2-cell embryos and determine their ability to develop to expanded blastocysts in vitro. We use the prefix "functional" for these functional survivals.

Survival based on morphology and membrane intactness-After warming from $-196^{\circ} \mathrm{C}$ and the 10-min exposure to $0.5 \mathrm{M}$ sucrose in PB1, the oocytes or 2-cell embryos were transferred to sucrose-free PB1 and then to Cook Cleavage medium (Catalog name: K$\mathrm{RVCL}$ ), in which they were incubated for $2 \mathrm{hrs}$ at $37^{\circ} \mathrm{C}$. The percentage exhibiting normal morphology and volumes at this point are scored as survivors.

\section{Functional survivals of oocytes based on IVF and ability to develop to expanded blastocysts}

After warming from $-196^{\circ} \mathrm{C}$ and the 10-min exposure to $0.5 \mathrm{M}$ sucrose in $\mathrm{PB} 1$, the oocytes were transferred into sucrose-free PB1, washed three times in Cook IVF medium (K-

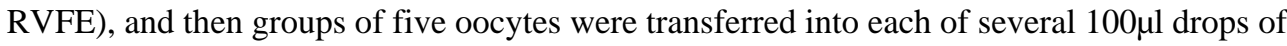
the IVF medium that contain a measured concentration of sperm. These pre-collected sperm had been diluted 100-fold initially and their concentration determined by haemocytometer. They were further diluted to produce samples containing $1 \times 10^{6}$ or $3 \times 10^{6} \mathrm{sperm} / \mathrm{ml}$, This translates to $2 \times 10^{4}$ and $6 \times 10^{4}$ sperm/oocyte. (Lower or higher concentrations of sperm yielded significantly poorer percentages of fertilization.) Note that the zona pellucidae were intact and untreated and still yielded high percentages of IVF. This is unlike the experience of Seki and Mazur [32], who obtained poor fertilization percentages unless the zonae were partially dissected. The difference is probably a consequence of our close attention to the sperm concentration.

After incubation for $5 \mathrm{hrs}$ in the Cook fertilization medium at $37^{\circ} \mathrm{C}$ under $5 \% \mathrm{CO}_{2} / 95 \%$ air, the now (hopefully) fertilized oocytes were transferred after washing from the Cook IVF medium to $100 \mu \mathrm{l}$ droplets of Cook Cleavage medium and incubated for 5 days under 5\% $\mathrm{CO} 2 / 95 \%$ air to permit development to expanded blastocysts. The Cook IVF medium is a variant of HTF medium and their Cleavage medium a variant of KSOM-AA medium, the compositions of which are given in [25].

\section{Statistics}

The main study involved 36 conditions; 18 for a laser-induced warming rate of $1.0 \times 10^{7}$ ${ }^{\circ} \mathrm{C} / \mathrm{min}$ and 18 for the control warming rate of $1.2 \times 10^{5}{ }^{\circ} \mathrm{C} / \mathrm{min}$, Each test condition was 
usually repeated 8 times $(\mathrm{N})$ with 5 oocytes per condition per run; i.e., 40 oocytes per condition. This amounts to 1440 oocytes in all. Errors are reported as Standard Errors; i.e., standard deviations of the mean.

\section{Results}

\section{Survival as a function of the osmolality of the vitrification medium and the warming rate}

Seki and Mazur [32] had determined that a high percentage of mouse oocytes survive vitrification in an EAFS solution diluted to half of normal if the oocytes were warmed at $117,000^{\circ} \mathrm{C} / \mathrm{min}$ on a Cryotop. They found, however, that only 5\% survived when EAFS was diluted 3-fold. The initial aim of the present study was to determine whether survival in a 3fold diluted solution could be increased by using a laser pulse to raise the warming rate as much as 100 -fold.

The Standard EAFS developed by Pedro et al. [27] for mouse oocytes consists of ethylene glycol (EG), acetamide, sucrose, and Ficoll dissolved in isotonic phosphate buffered saline (PB1). The oocyte is highly permeable to EG and acetamide [5,28], but is impermeable to the last three. This composition is typical of vitrification solutions in that it consists of permeable and non-permeable solutes, low and high molecular weight solutes, and has a very high total molality.

The $0.33 \times$ EAFS used by Seki and Mazur [30] is Solution No. 2 in Table 1. Its total molality is 1.72, about 1/4th that of full-strength EAFS. Solutions Nos. 1 and 3 to 10 give the compositions of modifications of the standard 0.33× EAFS. Nos. 11-13 represent solutions where no permeating solutes were present. The two right-hand columns give the osmotic/ morphological survival after laser warming at $10^{7}{ }^{\circ} \mathrm{C} / \mathrm{min}$ and after warming in a sucrose salt solution at $10^{5}{ }^{\circ} \mathrm{C} / \mathrm{min}$ with no laser.

Fig. 4 plots the survivals after the vitrification and warming of oocytes suspended in solutions where the total molalities ranged from 0.88 to 2.57 (solutions Nos. 5-11). In all except Solution 11, the molalities of EG and acetamide remained constant at 1.41 molal; In Solution 11, EG and acetamide were absent. The only variable in the former group was the concentration of sucrose which ranged from 0 to 1.0 molal. In initial experiments, the Cryotops were warmed at four different estimated rates; namely, $1.0 \times 10^{7}(\bullet), 3.0 \times 10^{6}$, $7.0 \times 10^{5}(\square)$, and $1.2 \times 10^{5}(\bigcirc){ }^{\circ} \mathrm{C} / \mathrm{min}$. In later experiments, only the first and 4 th rates were used. The three highest warming rates (calculated) were achieved with the use of the laser. The lowest warming rate was not.

Three curves are plotted; namely, survivals after warming at the lowest and highest rates, and at the mean of the two intermediate rates. All three curves are inverted "V"s, with maximum survivals of $92 \%$ in 2.07 molal solution, $93 \%$ in 1.82 molal, and $76 \%$ in 1.73 molal, for the fastest to slowest warming, respectively. With the fastest laser-induced warming, four of the 7 survivals exceeded $80 \%$ and all 7 were $70 \%$ or higher. In contrast, the survivals in 5 of the 7 sets warmed without the laser were below $70 \%$, and two were $0 \%$. We did obtain rather high survivals $(76 \%)$ with the non-laser warming if the oocytes were suspended in a 1.73 molal solution, but the survivals decreased abruptly when the molalities 
were decreased or raised slightly below or above that value. That is, the high survival response surface for the laser-warmed samples was much broader than that for the non-laser warmed samples.

An unanswered question at this point was whether survival was determined more by the total molality of the permeating solutes or by the total molality of both the non-permeating and permeating solutes. To answer this we performed the following experiment. Five solutions were prepared, each having a total molality of 2.0 but differing in the proportions of permeating solutes (EG + acetamide) to non-permeating (sucrose); namely, $\infty, 4.4,1.9$, 1.2 , and 0.84 . The molalities of $\mathrm{NaCl}$ and Ficoll were held constant at 0.15 and 0.0062 . The survivals after warming the samples at $1.0 \times 10^{7}{ }^{\circ} \mathrm{C} / \mathrm{min}$ by laser and at $1.2 \times 10^{5 \circ} \mathrm{C} / \mathrm{min}$ without the laser in a $23^{\circ} \mathrm{C}$ sucrose solution are given in Table 2 . With the laser-induced warming, there was no significant effect of changing the ratios of the molality of the permeating solutes to the molality of the nonpermeating from infinity to 1.9 , and the grand mean survival was $96 \%$. However, with the two lower ratios, the survivals dropped to 71 and $59 \%$. With non-laser warming at $1 / 75^{\text {th }}$ that rate, the grand mean survival was only $15 \%$, and there was a major effect of the ratios; i.e., solutions CTM 1 and CTM 2, which had ratios of $\infty$ and 4.4 , yielded a mean survival of $34 \%$ whereas, those with ratios of $1.9,1.2$, and 0.84 exhibited mean survivals of only $1.7 \%$.

Functional survivals-Functional survivals were determined for two of the conditions in Table 1 that yielded very high morphological and osmotic normality. These were solutions $0.33-4$ and $0.33-5$ (Numbers 7 and 8). The first assay was the ability of the oocytes vitrified in these solutions and warmed at the highest laser-induced rate $\left(1.0 \times 10^{7}{ }^{\circ} \mathrm{C} / \mathrm{min}\right)$ to undergo in-vitro fertilization and develop in vitro to expanded blastocysts. The results are shown in Table 3A. Some $90 \%$ of the oocytes had normal morphology after vitrification. A mean of $96 \%$ of those (columns 4/3) underwent fertilization and developed to the 2-cell stage, A mean of $60 \%$ of vitrified oocytes with normal morphology developed to expanded blastocysts as compared with $80 \%$ for fresh controls (columns $5 / 3$ ).

The second functional assay was the ability of in vivo -developed 2-cell embryos to survive vitrification in Solution 0.33-4 and laser warming, and develop in vitro into expanded blastocysts. The results are shown in Table 3B. A mean of $92 \%$ were morphologically normal after warming at the highest rate. Some $88 \%$ of these developed into expanded blastocysts, essentially the same as in the controls. Note the drastic negative effects in the controls warmed 100-times slower by omitting the laser (Table 3, footnote),

\section{Survival as a Function of the Molality of Sucrose in the Vitrification Medium}

Figure 4 depicted the survival of vitrified oocyte as a function of the total molality of the solutes in the experimental vitrification solution. The curves are inverted "V"s with the apex or optimum molality are the permeating solutes EG and acetamide and the non-permeating solute sucrose. The question of whether survival is primarily determined by the molality of the permeating solutes or by that of the non-permeant species is important. In Fig. 5 the molality of the sucrose has been extracted from the total molality, and survival is plotted against the former. The most important conclusion is that if the oocytes are warmed at the 
highest laser-driven rate (closed circles), the survivals after vitrification are $>80 \%$ with sucrose concentrations ranging from 0 to 0.5 molal. In contrast, when they are warmed about 100 times more slowly (open circles), survivals fall rapidly to $0 \%$ as the sucrose molality rises above 0.2 . The results are partly confounded by the fact that the concentrations of EG and acetamide are also changing over this range as can be seen for the appropriate solutions in Table 1.

\section{Survival after vitrification as a function of the molality of Ficoll in the vitrification medium}

The standard full strength $1 \times$ EAFS contains 0.0062 molal Ficoll (24.5 wt \%; 70,000 daltons), To assess its role we determined survivals after oocytes were vitrified in media in which the Ficoll concentrations were 0, 0.0013, and 0.0062 molal with all other components held constant. The results are shown in Fig. 6. Four curves are shown, two each for warming rates of $1.0 \times 10^{7}{ }^{\circ} \mathrm{C} / \mathrm{min}$ and $1.2 \times 10^{5}{ }^{\circ} \mathrm{C} / \mathrm{min}$. and two each for sucrose concentrations of 0.16 molal and 0.72 molal. In three of the four plots, the concentration of Ficoll has relatively little effect. These three cases are the ultra-rapid laser-induced warming of solutions made with both 0.16 and 0.72 molal sucrose (closed symbols), and the solutions containing 0.72 molal sucrose and warmed much more slowly at $1.2 \times 10^{5}{ }^{\circ} \mathrm{C} / \mathrm{min}$ (open squares). The exception was the solution prepared with 0.16 molal sucrose and warmed relatively slowly (open circles). In that case, survivals ranged from $0 \%$ in the absence of Ficoll to $76 \%$ in the presence of 0.0062 molal Ficoll. Another way to describe the results is that in 0.0062 molal Ficoll, survivals exceed $75 \%$ in three of the four cases and are tightly grouped. On the other hand, in the absence of Ficoll, the survivals show an extreme range from $0 \%$ to $86 \%$, the values depending on the sucrose concentration and warming rate.

We do not know the basis of the protection by Ficoll. It could be biological; e.g., it somehow protects the plasma membrane. But it also could be physical. For example, 0.0062 molal Ficoll has a weight percent of 24.5 in otherwise standard 0.33× EAFS (Solution 5 in Table 1). As such, its absence, the droplet spreads out. The change in geometry could affect the thermal energy that is seen by an oocyte, since it would affect the number of carbon particles the laser beam encounters before reaching the oocytes. Kuleshova et al. [12] reported that about $100 \%$ of 2 or 4-cell mouse embryos develop into expanded blastocysts if they were vitrified in media containing decreasing concentrations of EG and increasing concentrations of Ficoll. Their interpretation is that Ficoll has the ability to substitute for EG. But an alternative explanation could be that high embryo survival is obtained over about a 3 -fold range of EG concentrations irrespective of the Ficoll concentration, or vice-versa.

\section{Discussion}

Our main findings have been:

a. The warming rate has a major effect on survival. The highest survivals using the fastest laser-induced warming of $1.0 \times 10^{7}{ }^{\circ} \mathrm{C} / \mathrm{min}$ exceed those obtained using a rate of $1.2 \times 10^{5}{ }^{\circ} \mathrm{C} / \mathrm{min}(92 \%$ vs $76 \%$ ) (Fig. 4). Perhaps of even greater importance is that with this highest rate of warming, survivals remain high over a rather broad range of total molalities whereas when warming is 100-fold slower, high survivals are sharply restricted to a narrow zone of molalities. The greater sensitivity with the 
slower non-laser warming is also evident in Tables 1, 2, and Figs. 4 and 5. The poorer survivals with the slower warming are consistent with ascribing the lethality to the recrystallization of ice during warming.

In 1998, Fowler and Toner published a paper [7] relative to the importance of the rate of warming-a paper that has received too little attention. They first confirmed the published fact that if red cells in saline are cooled at about $10,000^{\circ} \mathrm{C} / \mathrm{min}$ to $-196^{\circ} \mathrm{C}, 100 \%$ hemolyze after warming at about $50,000^{\circ} \mathrm{C} / \mathrm{min}$ in a $37^{\circ} \mathrm{C}$ water bath. The standard interpretation is that the lethality is a consequence of the formation of abundant intracellular ice during cooling. On the other hand, they found the following treatment to produce a very different outcome. First, they cooled the red cells in the same way at that same rate to $-196^{\circ} \mathrm{C}$. Then the cells themselves, but not the surrounding saline medium, were warmed back above $0^{\circ} \mathrm{C}$ at a calculated rate of $10^{11}{ }^{\circ} \mathrm{C} / \mathrm{min}$ by the application of a nano second- duration laser pulse emitting at the absorbance peak of haemoglobin $(532 \mathrm{~nm})$. This caused the intracellular ice to melt and produced a $200^{\circ} \mathrm{C}$ difference between the temperature of the cells and the frozen medium. Consequently, when the pulse ended, the cells cooled back to $-170^{\circ} \mathrm{C}$ at an estimated rate of $60,000,000^{\circ} \mathrm{C} / \mathrm{min}$ and vitrified. If the now vitrified samples were then warmed from $-170^{\circ} \mathrm{C}$ at the standard $50,000^{\circ} \mathrm{C} / \mathrm{min}$ in a water bath, $80 \%$ survive. Their interpretation is that the cells will survive the formation of even sizeable amounts of intracellular ice if the warming rate is extremely and sufficiently high. We agree, but with two caveats. One is that other factors that we have discussed define "sufficiently high". One of these is the degree to which the cells are dehydrated before cooling. The second caveat, is that their particular technique requires cells that either naturally possess a laser-absorbing chromophore or are cells into which the chromophore can be injected.

b. Survival after vitrification and warming is strongly dependent on the total molality (and therefore, osmolality) of the suspending medium. The optimum total concentration is close to 2.0 molal. (We express concentrations as molalities rather than molarities because the former are much closer approximations than the latter to the chemical potentials of water and the solutes in the medium. It is the differences between these chemical potentials outside the cell and those inside the cell that determine the direction and rate of the movement of water and solutes under the conditions we are discussing).

c. Survival is not dependent, or only weakly dependent, on the mole ratio of the permeating to non-permeating solutes. The data supporting this conclusion are in Table 2. The permeating solutes here are EG and acetamide.

d. Survival after vitrification appears to be importantly affected by the extent to which the oocytes or embryos have become dehydrated just prior to vitrification. When cells are exposed to hyperosmotic solutions like those used here, they undergo abrupt osmotic shrinkage to a minimum volume, the value of which is determined by the ratio of the isotonic osmolality ( 0.3) to the total osmolality (nonpermeating plus permeating solutes). This initial abrupt shrinkage is primarily a 
manifestation of water loss. It is abrupt because the permeability of cells to water is usually much higher than their permeabilities to solutes. The abrupt shrinkage is then followed by a slower swelling to a final equilibrium water volume, the rate of which depends primarily on the permeability coefficients of the permeating solutes. The final equilibrium volume is equal to the ratio of the osmolality of the solutes in an isotonic cell to the osmolality of the non-permeating solutes in the medium. Pedro [28] has shown that the optimum time in EAFS before vitrification is $2 \mathrm{~min}$ for the ICR mouse oocyte. Others such as [33] have reported even shorter times. That elapsed time is probably very close to the exposure time that produces the maximum shrinkage of the cells, and is a time at which relatively few molecules of permeating solute have entered the cell. Quantitative estimates of how few will have to await experimental measurements of oocyte volumes vs. time in EAFS solutes and estimates of their permeability to water and to the solutes. But our quasi-quantitative analysis supports the view that the ability of the EAFS solutes to protect the cells is primarily due to the extensive cell dehydration they produce prior to initiating vitrification and is only to a very limited extent a consequence of the permeation of EG and acetamide into the oocytes.

e. Optimal media for survival after warming at the highest laser-induced rate. Among the optimal media were Solutions 0.33-4 and 0.33-5. With them, morphological/ osmotic survivals and functional survivals were $\geq 80 \%$ with both cell stages (Tables 1, 3). Functional survival based on the IVF of oocytes and development to the 2-cell stage was $86 \%$ (Table $3 \mathrm{~A}$, column 4 ). This is higher than the $81 \%$ reported by Seki and Mazur [32] for oocytes vitrified in full-strength EAFS and subjected to partial zona dissection prior to IVF. In our current study, $88 \%$ of invivo derived 2-cell embryos were able to develop to expanded blastocysts after suspension in 3-fold diluted EAFS, vitrification, and laser-induced warming (Table 3B, column 5)). This is almost as high as the 92\% that Seki, Jin, and Mazur [29] have reported for the percentage of 8-cell embryos vitrified in full-strength EAFS that develop to blastocyst.

As summarized in Table 4, our findings conflict with several current orthodox views on vitrification. With respect to the solute concentration in the vitrification solution (VS), scattered publications aside from ours have obtained good survivals of human and mouse oocytes using 1.5 M or $2 \mathrm{M}$ VS [3,14]. Indeed, Katkov, Isachenko and colleagues [10] have reported $\sim 15 \%$ morphological survival (motility?) of sperm vitrified using no added cryoprotectant. We have obtained up to $92 \%$ survival with 1.8 molal VS provided we use laser assisted warming. This concentration approaches the 1.64 molal $(1.5 \mathrm{M})$ concentrations of EG and glycerol that we and others have used in slow freezing studies. The hope is that the ability to use much lower solute concentrations will reduce or eliminate adverse effects associated with the standard multi-molal solutions.

With respect to the permeation of VS solutes into cells, we obtain high survivals when the vitrification medium contains zero permeating solutes (Table 1, solutions 11, 12, and 13).. We also obtain very high survivals when the protective media contain permeating solutes, but the 2.0 min exposure time prior to initiating vitrification is so short that very little 
permeating solute has time to enter the cells. These findings lead to the conclusion that protection arises much more from extensive osmotic cell water loss that from the penetration of VS solutes.

Most studies have placed emphasis on the need for the cooling rate to be extremely high, and with one exception, we used a cooling rate of $69,000^{\circ} \mathrm{C} / \mathrm{min}$ in the experiments reported here. In that one exception, however, oocytes in Solution $0.33 \mathrm{x}-4$ of Table 1 were cooled at about $10,000^{\circ} \mathrm{C} / \mathrm{min}$ on a Cryotop and laser warmed at $1.0 \times 10^{7}{ }^{\circ} \mathrm{C} / \mathrm{min}$. This 7 -fold slower cooling was achieved by placing the Cryotop blade in liquid nitrogen vapor for 15 to $30 \mathrm{~s}$ about $6 \mathrm{~mm}$ above the surface of the liquid nitrogen. The temperature there is $\sim-160^{\circ} \mathrm{C}$. The blade was then immersed in $\mathrm{LN}_{2}$ and laser warmed as usual. Survival was $95.5 \pm 3.3 \%$ $(\mathrm{N}=6)$, which is close to the $92 \%$ survival obtained for the cells cooled 7-times more rapidly in Table 1. Moreover, Seki, Jin, and Mazur [29,32] had previously determined that high survivals can be obtained with even slower cooling $\left(880^{\circ} \mathrm{C} / \mathrm{min}\right)$ provided that the warming is very rapid.

\section{Relevance of our findings to other cell types}

Our choice of the mouse oocyte as the test cell was based more on its elegance and utility in elucidating fundamental aspects of cryobiology than on the applied purpose of cryopreserving mouse oocytes. They and human oocytes can be preserved reasonably well now by classical slow equilibrium freezing and by orthodox vitrification procedures. Still, the combination of much lower concentrations of protective solutes and laser-driven ultra rapid warming could yield substantial improvements. However, where the present study may have especially important applications and implications is with cell types that currently can not be fully cryopreserved either by slow equilibrium freezing or by orthodox vitrification [20]. The group includes the oocytes and embryos of essentially all non-mammalian vertebrates such as zebrafish and amphibians. It includes the embryos of nearly all invertebrates examined such as mollusks. echinoderms, and most insects (Drosophila is a partial exception [19,34]). It includes certain individual mammalian cells and thin tissues such as granulocytes, corneas, and Islets of Langerhans. In many of these cases success seems close at hand and yet remains elusive. One requirement for success by laser-assisted ultra-rapid warming is that the cell or tissue be small or thin enough to respond without excessive lag to the energy provided by the laser. The main reason for this is that if the India Ink particles are restricted to the medium outside the cell, the warming of the cell has to occur by the conduction of heat from that medium to the cell interior. The larger the cell, the longer that path becomes and the more it becomes the limiting factor in the maximum warming rate that can be attained for the cell. Also, the larger the cell, the greater might be differences in warming rate in different regions of the cell. However, the results of modeling described in Fig. 7 in the Appendix show that no such differences are discernible at a warming rate of $10^{7}{ }^{\circ} \mathrm{C} / \mathrm{min}$ in a cell with a diameter of $75 \mu \mathrm{m}$. Our rough calculations suggest that our laser could warm cells and tissues with cells or tissues with diameters or thicknesses of $750 \mu \mathrm{m}$ as rapidly as $10^{6}{ }^{\circ} \mathrm{C} / \mathrm{min}$ without these problems becoming crippling; i.e., $1 / 10^{\text {th }}$ the maximum rate used here. That size encompasses many of the problem cell and tissue types listed above. Consequently, we are optimistic that a reinvestigation of their vitrification in light of our new findings could well prove rewarding. Unfortunately, 
however, our approach does not appear amenable to the vitrification of whole organs and large masses of tissue, systems that have been investigated by the elegant work of Fahy [6] and others. They are too large to permit ultra rapid warming.

\section{Acknowledgments}

The research reported here was supported by NIH grant 5R01-OD011201, P. Mazur, PI. We appreciate the support of the Division of Comparative Medicine in the Office of the Director at NIH over the past nine years. We also wish to thank Dr. Robert Compton of the Department of Chemistry for his initial encouragement of the laser approach, Dr. Stanley P. Leibo of the Department of Biology at the University of New Orleans for his assistance in unscrambling some of the problems we have had with IVF and invitro development, and Estefania Parade, a predoctoral student, for measurements of the optical densities of India Ink suspensions..

\section{References}

1. Borini, A.; Goticchio, G. Preservation of Human Oocytes-From Cryobiology Science to Clinical Applications. Gardner, D.; Gerris, J.; Shoham, Z., editors. Informa Healthcare; London: 2009.

2. Cobo A, Bellver J, Domingo J, Perez S, Crespo J, Pellicer A, Remohi J. New options in assisted reproduction technology: the Cryotop method of oocyte vitrification. Rep Biomed Online. 2008; 17:68-72.

3. Criado E, Albani E, Novara PV, Smeraldi A, Cesana A, Parini V, Levi-Setti PE. Human oocyte ultravitrification with a low concentration of cryoprotectants by ultrafast cooling: a new protocol. Fertil Steril. 2010; 95:1101-1103. [PubMed: 21130433]

4. Dorsey, NE. American Chemical Society Monograph Series. Vol. 81. Reinhold Publishing Co; New York: 1940. Properties of Ordinary Water-Substance.

5. Edashige K, Ohta S, Tanaka M, Kawano T, Valdez DM Jr, Hara T, Yakahashi S, Seki S, Koshimoto $\mathrm{C}$, Kasai M. The role of Aquaporin 3 in the movement of water and cryoprotectants in mouse morula. Biol Reprod. 2007; 77:365-375. [PubMed: 17429015]

6. Fahy GM, Wowk B, Wu J, Phan J, Rasch C, Chang A, Zendejasl E. Cryopreservation of organs by vitrification: perspectives and recent advances. Cryobiology. 2004; 48:157-178. [PubMed: 15094092]

7. Fowler AJ, Toner M. Prevention of hemolysis in rapidly frozen erythrocytes by using a laser pulse. Annals NY Academy of Sciences. 1998; 858:245-252.

8. Grebowicz J, Lau SF, Wunderlich B. The thermal properties of polypropylene. J Polymer Science: Polymer Symposia. 1984; 71:19-37.

9. Karlsson J, Cravalho E, Rinkes H, Tompkins RG, Yarmouth ML, Toner M. Nucleation and growth of ice crystals inside cultured hepatocytes during freezing in the presence of dimethyl sulfoxide. Biophys J. 1993; 65:2524-2536. [PubMed: 8312489]

10. Katkov II, Isachenko V, Isashenko E, Kim MS, Lulat AGMI, Mackay AM, Levine F. Low- and high-temperature vitrification as a new approach to biostabilization of reproductive and progenitor cells. International J Refrigeration. 2006; 29:346-367.

11. Kleinhans FW, Seki S, Mazur P. Simple inexpensive attainment and measurement of very high cooling and warming rates. Cryobiology. 2010; 61:231-233. [PubMed: 20599881]

12. Kuleshova LL, Shaw JM, Trounson AO. Studies on replacing most of the penetrating cryoprotectants by polymers for embryo cryopreservation. Cryobiology. 2001; 43:21-31. [PubMed: 11812048]

13. Kuwayama M. Highly efficient vitrification for cryopreservation of human oocytes and embryos: The Cryotop method. Theriogenology. 20077; 67:3-80.

14. Lee HJ, Elmoazzen H, Wright D, Biggers J, Rueda BR, Heo YS, Toner M, Toth TL. Ultra-rapid vitrification of mouse oocytes in low cryoprotectant concentrations. Reproductive Biomedicine Online. 2010; 20:201-208. [PubMed: 20113958]

15. Liu Y, Cheng DK, Sonek GJ, Berns MW, Chapman CF, Tromberg BJJ. Evidence for localized cell heating induced by infrared optical tweezers. Biophys J. 1995; 68:2137-2144. [PubMed: 7612858] 
16. Madsen S, Patterson M, Wilson B. The use of India Ink as an optical absorber in tissue-simulating phantoms. Phys Med Biol. 1992; 37:985-993. [PubMed: 1589459]

17. Mazur P. Cryobiology: The freezing of biological systems. Science. 1970; 168:939-949. [PubMed: 5462399]

18. Mazur, P. Principles of Cryobiology. In: Fuller, BJ.; Lane, N.; Benson, E., editors. Life in the Frozen State. CRC Press; Boca Raton: 2004. p. 3-65.

19. Mazur P, Cole KW, Hall JW, Schreuders PD, Mahowald AP. Cryobiological preservation of Drosophila embryos. Science. 19921; 258:932-1935.

20. Mazur P, Leibo SP, Seidel GE Jr. Cryopreservation of the germplasm of animals used in biological and medical research: Importance, impact, status, and future directions. Biology of Reproduction. 2008; 78:2-12. [PubMed: 17901073]

21. Mazur P, Pinn IL, Kleinhans FW. Intracellular ice formation in mouse oocytes subjected to interrupted rapid cooling. Cryobiology. 2007; 55:158-166. [PubMed: 17686470]

22. Mazur P, Schneider U. Osmotic response of preimplantation mouse and bovine embryos and their cryobiological implications. Cell Biophys. 1986; 8:250-285.

23. Mazur P, Seki S, Pinn IL, Kleinhans FW, Edashige K. Extra- and intracellular ice formation in mouse oocytes. Cryobiology. 2005; 51:29-53. [PubMed: 15975568]

24. Mazur P, Seki S. Survival of mouse oocytes after being cooled in a vitrification solution to $-196^{\circ}$ $\mathrm{C}$ at $95^{\circ}$ to $70,000^{\circ} \mathrm{C} / \mathrm{min}$ and warmed at $610^{\circ}$ to $118,000^{\circ} \mathrm{C} / \mathrm{min}$ : A new paradigm for cryopreservation by vitrification. Cryobiology. 2011; 62:1-7. [PubMed: 21055397]

25. Nagy, A.; Gertsenstein, M.; Vintersten, K.; Behringer, R. Manipulating the Mouse Embryo: A Laboratory Manual. 3. Vol. 3. Cold Spring Harbor Laboratory Press; Woodbury, NY: 2003. p. 570p. 572p. 577-579.

26. Parades E, Mazur P. The survival of mouse oocytes shows little or no correlation with the vitrification or freezing of the external medium, but the ability of the medium to vitrify is affected by its solute concentration and by the cooling rate. Cryobiology. 2013; 67:386-390. [PubMed: 24056038]

27. Pedro PB, Zhu SE, Makino N, Sakurai T, Edashige K, Kasai M. Effects of hypotonic stress on the survival of mouse oocytes and embryos at various stages. Cryobiology. 1997; 35:150-158. [PubMed: 9299106]

28. Pedro, P. PhD thesis. Vol. Chapter 3. United Graduate School of Agricultural Sciences, Ehime University; 1997. Studies on the cryopreservation of mammalian oocytes and embryos with reference to some cryobiological characteristics.

29. Seki S, Jin B, Mazur P. Extreme rapid warming yields high functional survival of 8-cell mouse embryos even when suspended in a half-strength vitrification solution and cooled at moderate rates to $-196^{\circ}$ C. Cryobiology. 2014; 68:21-28.

30. Seki S, Mazur P. Effect of warming rate on the survival of vitrified mouse oocytes and on the recrystallization of intracellular ice. Biology of Reproduction. 2008; 79:727-737. [PubMed: 18562703]

31. Seki S, Mazur P. Kinetics and activation energy of recrystallization of intracellular ice in mouse oocytes subjected to interrupted rapid cooling. Cryobiology. 2008; 56:171-180. [PubMed: 18359013]

32. Seki S, Mazur P. Ultra-rapid warming yields high survival of mouse oocytes cooled to $-196^{\circ} \mathrm{C}$ in dilute vitrification solutions. PLoS One. 2012; 7(4):e36058. [PubMed: 22558325]

33. Shaw PW, Bernard AG, Fuller BJ, Hunter H, Shaw RW. Vitrification of mouse oocytes using short cryoprotectant exposure: Effect of varying exposure times on survival. Mol Reprod Dev. 1992; 33:210-214. [PubMed: 1418991]

34. Steponkus PL, Myers SP, Lynch DV, Gardner L, Bronshteyn V, Leibo SP, Rall WF, Pitt RE, Lin TT, MacIntyre RJ. Cryopreservation of Drosophila melanogaster embryos. Nature. 1990; 345:170-172. [PubMed: 2110627]

35. Wagner TR, Houf WG, Incropera FP. Radiative property measurements for India ink suspensions of varying concentration. Solar Energy. 1980; 25:549-554.

36. Whittingham DG, Leibo SP, Mazur P. Survival of mouse embryos frozen to -196 and -269 C. Science. 1972; 178:411-414. [PubMed: 5077328] 
37. Zhang H, Liu KK. Review: Optical tweezers for single cells. JR Soc Interface. 2008; 5:671-690.

\section{APPENDIX}

\section{The laser, the laser pulse, the Cryo Jig, and the resultant warming rates}

\section{Achieving ultra-rapid warming by a pulse of an infrared laser}

As stated, our hypothesis is that the lower the concentration of solutes in the vitrification medium, the less will be the damaging effects of those solutes but the higher the warming rate will have to be to preclude damage from the recrystallization of intracellular ice. Thus, we wished to investigate the effects of warming rates 10 to 100-fold higher than the maximum of $10^{5} \mathrm{C} / \mathrm{min}$ currently attainable with Cryotops transferred from $\mathrm{LN}_{2}$ into a room-temperature solution; i.e., rates of $10^{6}$ and $10^{7}{ }^{\circ} \mathrm{C} / \mathrm{min}$. A magnified view of the polypropylene blade at the tip end of a Cryotop is shown in Fig. 1. It measures $0.7 \mathrm{~mm}$ wide $\times 20 \mathrm{~mm}$ long $\times 0.1 \mathrm{~mm}$ thick. (The thermocouple was not present in the experiments reported here.)

Such rates are not attainable by plunging thin plastic strips with adhering small droplets of oocyte suspensions into a warm water bath. They are, however, attainable by laser heating. To warm at $10^{6}$ and $10^{7}{ }^{\circ} \mathrm{C} / \mathrm{min}$, laser energy has to be delivered and absorbed in 10.6 and $1.06 \mathrm{msec}$, respectively ( $\mathrm{WR}=\Delta \mathrm{T} / \Delta \mathrm{t}$, where $\Delta \mathrm{T}$ is the temperature range and $\Delta \mathrm{t}$ is the time to traverse that range, which is equal to the duration of the laser pulse). We derived delta $\mathrm{T}$ as follows: When the Cryotop is removed from $\mathrm{LN}_{2}$, we estimate that it takes about $0.1 \mathrm{sec}$ for the residual liquid nitrogen to evaporate. Warming at $130^{\circ} \mathrm{C} / \mathrm{s}$ [24] then begins from contact with $23^{\circ} \mathrm{C}$ air. The laser fires an estimated $0.15 \mathrm{~s}$ later. Consequently, during this $0.15 \mathrm{~s}$, the Cryotop and sample have warmed an estimated $20^{\circ} \mathrm{C}$. Thus, rounding off, we take $-180^{\circ} \mathrm{C}$ as the starting temperature of the laser pulse. Of course, air warming at $\sim 10^{4}$ ${ }^{\circ} \mathrm{C} / \mathrm{min}$ continues even after the laser pulse turns on, but its contribution to warming is only about $1 / 10^{\text {th }}$ to $1 / 1000^{\text {th }}$ of the laser pulse. The end point occurs at $-3.5^{\circ} \mathrm{C}$, the melting point of $0.33 \times$ EAFS solutions. Thus, the value of $\Delta \mathrm{T}$ is $176.5^{\circ} \mathrm{C}$.

\section{Energy to heat and melt the samples}

Calculations based on the masses and specific heats of the components $(0.1 \mu \mathrm{l}$ sample of oocytes in EAFS on a Cryotop) show that it requires 0.037 joules to warm the assembly from $-180^{\circ} \mathrm{C}$ to $-3.5^{\circ} \mathrm{C}$. Parades and Mazur [26] have found that when $0.33 \times$ EAFS is cooled at $69,000^{\circ} \mathrm{C} / \mathrm{min}$, it freezes and does not vitrify. Consequently, we have modeled the system to consist of $0.1 \mathrm{mg}$ ice and $0.06 \mathrm{mg}$ for the $1 \mathrm{~mm}$ portion of the polypropylene blade that is warmed from $-180^{\circ} \mathrm{C}$ to $-3.5^{\circ} \mathrm{C}$ by the laser pulse. Two-thirds of this energy is required to warm the ice in the sample and the remainder to warm the blade of the Cryotop. There were usually five oocytes on a Cryotop but their total volume $(0.002 \mu \mathrm{l})$ can be neglected, for it is only $1 / 50^{\text {th }}$ the volume of the droplet $(0.1 \mu \mathrm{l})$.

Because of the solutes in the sample, a small amount of melting begins at the eutectic point of the solution ( $-60^{\circ} \mathrm{C}$ for EAFS), it increases as warming progresses, and is complete at $-3.5^{\circ} \mathrm{C}$, the melting point of the sample (The freezing point depression is 2 molal times $1.866^{\circ} \mathrm{C} / \mathrm{mole}$ ). The energy required for melting (latent heat of fusion) is estimated as the 
energy to melt $0.1 \mu \mathrm{l}(0.1 \mathrm{mg})$ of ice, which is $0.033 \mathrm{~J}$. This is comparable to the energy required to warm the sample from $-180^{\circ} \mathrm{C}$. Thus the total energy required to warm the sample from $-180^{\circ} \mathrm{C}$ and melt it at $-3.5^{\circ} \mathrm{C}$ is $0.070 \mathrm{~J}$.

In practice, the laser energy is adjusted to just melt our samples as visualized immediately after the laser pulse through the built in $15 \mathrm{x}$ stereo microscope. It would have been advantageous to stop just short of melting but we know of no way to monitor such an end point. Laser settings to achieve melting were determined or confirmed with several trial shots at the beginning of each day's experimental run. Good consistency in survivals is obtained with this procedure.

The laser that best met our requirements was a pulsed Nd:YAG laser emitting in the IR at $1064 \mathrm{~nm}$ manufactured by LaserStar Technologies [Riverside, RI, USA]. The model of choice was a 990 Series iWeld 40 Joule Laser costing $\$ 18,000$ (Fig. 3). With some restrictions near the ends of the ranges, it can deliver 0.1 to 40 joule pulses in 0.5 to $30 \mathrm{msec}$ with a beam diameter of 0.05 to $2 \mathrm{~mm}$. The primary market for this laser is welding operations by jewelers. An important consequence of this is that the machine has a number of built-in safety features.

\section{Considerations of thermal energy absorbed by the target and oocytes}

The important consideration is not the energy emitted by the laser, but the fraction of that radiant energy that is absorbed by the EAFS medium and the oocytes. The most important consideration here is that water only absorbs $\sim 2 \%$ of the $1064 \mathrm{~nm}$ IR emitted by our laser [ 4 (Table 160)]. Our $\sim 2$ molal modified EAFS solutions have a slightly higher absorption which we estimate at $\sim 3.5 \%$ based on measurements of sample melting as a function of the ink concentration extrapolated to zero. Still, the point remains that the absorption by our samples is very low. Fortunately, there turned out to be a simple solution; namely, add a material to the suspension that does absorb that wavelength strongly and is non toxic. The material we chose was a suspension of carbon black in the form of Higgins \# 44201 Waterproof Black India Drawing Ink. Its absorbance properties have been shown by Wagner et al. [35] and Madsen et al.[16] to approximate those of an ideal black body; namely, a body that absorbs radiation over a broad range of wavelengths.

Counter-intuitively, it was important to keep the transmittance of the sample high (optical density low). In other words, the majority of the beam energy needs to pass right through the sample. The reason is that if the transmittance were low, the front part of the sample would receive most of the incident energy, and rearward portions would be shadowed. Keeping the transmittance high produces a relatively even deposition of energy throughout the depth of the sample. After initial experimental work, we chose $80 \%$ transmission through the $0.1 \mu \mathrm{l}$ sample. This means the back or 'exit' side of our sample will receive $80 \%$ of the heating received by the front or 'entrance' side. On the basis of a droplet thickness of $0.3 \mathrm{~mm}$ and our measured Higgins ink absorbtivity in $0.33 \times$ EAFS of $1.38 \%{ }^{-1} \mathrm{~mm}^{-1}$ at $1064 \mathrm{~nm}$, we calculated the required ink concentration to be about $0.25 \%$ using the Beer-Lambert Law. That is somewhat approximate because we found bottle to bottle variations in the absorbtivity of the Ink. An ink concentration of only 2.5 parts in 1000 would not be 
expected to injure the oocytes, especially since the India Ink particles are far too large to pass through the zona pellucida of the oocyte and come in contact with the cell surface.

We purchased the 990 Series iWeld 40 Joule laser with a so-called 'Soft Touch' profile which produces a more even power distribution across the beam profile than the standard Gaussian profile. This provides a more uniform heating of our sample and reduces the demands on the accurate XY positioning of the sample. Consider a spatially uniform $2 \mathrm{~mm}$ diameter beam. The cross sectional area of the cryo sample is $\sim 0.6 \mathrm{~mm} \times 0.6 \mathrm{~mm} \approx 0.36$ $\mathrm{mm}^{2}$ with $80 \%$ transparency or $20 \%$ absorption, and the sample intercepts and absorbs a fraction of the beam energy equal to:

$$
E f=\left[\frac{\text { Area } a_{-} \text {sample }}{\text { Area }_{-} \text {beam }}\right] * \text { Sample } \text { absorption }=0.04
$$

Thus, the sample absorbs $4 \%$ of the incident energy. Since the energy delivered by the laser exceeds $6 \mathrm{~J}$ per pulse in the regimes of interest, it can deposit as much as $0.24 \mathrm{~J}$ of energy in the sample. In other words, the available laser energy that could be deposited in the sample is about three times the $0.070 \mathrm{~J}$ needed to warm the sample from $-180{ }^{\circ} \mathrm{C}$ and melt it at $-3.5^{\circ} \mathrm{C}$.

\section{Potential oocyte damage from a laser pulse}

Having calculated the required laser power and knowing the area over which it is distributed, we can address the potential for direct damage to the oocytes from the laser pulse. Extensive literature on optical tweezers demonstrates that laser intensities (watts/area) of as much as 150 times the maximum that we have used have no demonstrable effect on, for example, Chinese hamster ovary cells [15,37]. Furthermore, we have shown experimentally in Table 1 that the laser powers sufficient to warm the oocytes at the maximum calculated rate still produce survivals of $>90 \%$. Thus there is neither theoretical nor experimental evidence for oocyte damage from the laser beam itself.

\section{Details of the warming pulse}

We have developed considerable evidence that the main cause of injury during the warming of oocytes is the recrystallization of intracellular ice. On both the basis of experiments in our laboratory with oocytes and on theory, recrystallization does not occur in oocytes below $-100^{\circ} \mathrm{C}$ nor above $\sim-30^{\circ} \mathrm{C}[31,32]$. Hence, it is this temperature range over which the warming rate is expected to have major biological effects. The warming rate is determined by the laser power, the sample mass, and its thermal properties (heat capacity and heat of fusion). From discussions with the Laser Star engineers, F.W.K. estimates the laser power to be constant to $\sim 5 \%$, and, of course, the sample mass is constant. The sample thermal properties are more complex. In this temperature range $\left(-100\right.$ to $\left.-30{ }^{\circ} \mathrm{C}\right)$, the specific heat of the target (sample and Cryotop) rises somewhat with temperature. In ice, it is 0.43 $\mathrm{cal} /{ }^{\circ} \mathrm{C} / \mathrm{g}$ at $-40^{\circ} \mathrm{C}$ [4] compared to $0.5 \mathrm{cal} /{ }^{\circ} \mathrm{C} / \mathrm{g}$ at $0^{\circ} \mathrm{C}$, a difference of only $14 \%$. The specific heat of the polypropylene blade rises similarly with rising temperature [8]. And, as the specific heat capacity of the sample rises, the warming rate diminishes (since more energy is required for a given temperature change). However, the effect on the warming rate 
is small compared to the 10 to 100 -fold range in rates we have used. A second factor that alters the thermal properties of the target is the melting which begins at the eutectic point of the EAFS solutions $\left(\sim-60^{\circ} \mathrm{C}\right)$. As the temperature rises, increasing portions of the laser energy go to melt the EAFS rather than warming it. This also slows down the warming rate over what it would otherwise be, as discussed in a separate section further below.

To summarize the important power and temperature issues, the ice crystallization events we are interested in occur between $-100^{\circ} \mathrm{C}$ and $\sim-30^{\circ} \mathrm{C}$. The sample starts at $-196^{\circ} \mathrm{C}$ in $\mathrm{LN}_{2}$ and warms to $\sim-180^{\circ} \mathrm{C}$ in air. At that point, the laser fires and warms the sample to $-3.5^{\circ} \mathrm{C}$ and melts it. The sample then warms in air to room temperature. Assuming the laser pulse warms the sample from $-180^{\circ} \mathrm{C}$ to $-3.5^{\circ} \mathrm{C}$, laser pulse durations of $\sim 10$ and $1 \mathrm{msec}$ yield warming rates $(\Delta \mathrm{T} / \Delta \mathrm{t})$ of $1 \times 10^{6}$ to $1 \times 10^{7}{ }^{\circ} \mathrm{C} / \mathrm{min}, 10$ to 100 times faster than our traditional method, as desired.

\section{Temperature gradients and variations in warming rate in oocytes in response to laser warming}

The warming rates reported throughout this paper are based on $\mathrm{WR}=\Delta \mathrm{T} / \Delta \mathrm{t}$ where $\Delta \mathrm{T}$ is the change in temperature from -180 to $-3.5^{\circ} \mathrm{C}$ and $\Delta \mathrm{t}$ is the duration of the laser pulse (controlled with the laser settings). Two factors make this an over simplification of the actual warming rate experienced by the oocytes. One is that the warming rate inside the oocytes may be less than the laser-induced warming rate in the surrounding medium because of thermal lag; the second is that the warming rate above the eutectic point $\left(\sim-60^{\circ} \mathrm{C}\right)$ is progressively slowed by the melting of an increasing fraction of the ice.

Since the cells and the EAFS media themselves absorb only an insignificant fraction of the incident laser energy, our procedure has been to suspend the mouse oocytes in a dilute suspension of India ink particles in diluted EAFS vitrification solutions. It is the ink particles that are the primary absorber of the laser energy and are heated by it. That heat is then transmitted to the surrounding EAFS solution, and transmitted from there to the surface of the oocyte and then to its interior. The questions are how long does this energy transfer take? What sort of thermal lags does it induce? And how much does the warming rate in the oocyte differ from that of the external medium and vary within different regions in the oocyte.

To examine this problem, a simple, finite element analysis of Fourier heat conduction was developed using Microsoft Excel. A brief outline is given here with details to follow in a future publication. First, the entire system was taken to have the thermal properties of pure ice, with warming starting at $-180{ }^{\circ} \mathrm{C}$, the temperature at which the laser pulse turns on. Absorption of the laser beam energy is assumed to be exclusively via the India Ink particles in the EAFS. We chose the finite elements to be $2 \mu \mathrm{m}$ thick spherical shells. We then broke the system into three concentric regions. The outer one is a 'sea' of EAFS solution (and India Ink particles) far from the oocyte. We assume that it responds perfectly to the laser warming ramp (pulse) with a temperature given by $\mathrm{T}_{1}=-180+\mathrm{WR} * \mathrm{t}$, where $\mathrm{t}$ is the length of time the laser pulse has been on. 
Interior to the "sea" is a second region taken to be a shell of $0.3 \times$ EAFS and India Ink located between $100 \mu \mathrm{m}$ and $47.5 \mu \mathrm{m}$ from the center of the oocyte. The $47.5 \mu \mathrm{m}$ radius lies at the outer surface of the zona pellucida of the extended oocyte $(47.5 \mu \mathrm{m}$ becomes $48 \mu \mathrm{m}$ in the model because the model resolution is only $2 \mu \mathrm{m}$ ). The temperature at the $100 \mu \mathrm{m}$ outer boundary of region II is set at the temperature of the EAFS 'sea'. We judge this boundary condition to be a good approximation, as this second region has eight times the volume of the extended oocyte and thus provides a good thermal 'boundary zone' between the oocyte and the EAFS sea. Three thermal effects operate in this second region. Heat is being 'added' to it by the laser and from the "sea and" heat is being removed from it by the cold oocyte. The change in temperature of an element in this region during one time step, $\delta$ t, is given by:

$$
\mathrm{T}^{\prime}=\mathrm{T}_{\mathrm{o}}+\mathrm{WR} * \delta \mathrm{t}+\left(1 / \mathrm{c}_{\mathrm{p}} * \mathrm{~g}\right)\left[(\mathrm{k} * \delta \mathrm{t} / \delta \mathrm{r})\left(\mathrm{A}_{\mathrm{U}} * \delta \mathrm{T}_{\mathrm{U}}-\mathrm{A}_{\mathrm{L}} * \delta \mathrm{T}_{\mathrm{L}}\right)\right]
$$

where:

$\mathrm{T}^{\prime}$ and $\mathrm{T}_{\mathrm{o}}$ are the new and old element temperatures of the element being evaluated,

$\mathrm{WR}$ is the warming rate and $\mathrm{WR} * \delta \mathrm{t}$ is the laser component of temperature change, $\mathrm{c}_{\mathrm{p}}$ and $\mathrm{k}$ are the specific heat capacity and thermal conductivity of ice, taken to be: $\mathrm{c}_{\mathrm{p}}=$ $1.67 \mathrm{~J} / \mathrm{g} / \mathrm{K}$ and $\mathrm{k}=3.0 \mathrm{~W} / \mathrm{m} / \mathrm{K}$, chosen at $\sim-70^{\circ} \mathrm{C}$, the middle of the temperature range of prime interest between -100 and $-30{ }^{\circ} \mathrm{C}$,

$\mathrm{g}$ is the mass of the spherical shell in question and $\delta \mathrm{r}$ is the finite element step size, 2 $\mu \mathrm{m}$,

$A_{U}$ and $A_{L}$ are the upper ( $r$ greater) and lower ( $r$ lesser) surface areas of the adjacent shells to the one being evaluated,

$\delta \mathrm{T}_{\mathrm{U}}$ and $\delta \mathrm{T}_{\mathrm{L}}$ are the differences in temperature between the upper shell and shell in question and similarly for $\delta \mathrm{T}_{\mathrm{L}}$.

The third region is that of the extended oocyte. This is the $47.5 \mu \mathrm{m}$ region between the zona pellucida and the center of the oocyte. It is modeled with the same above equation except that there is no India Ink present; therefore there is no direct laser warming, and as a consequence, we omit the term $\mathrm{WR} * \delta \mathrm{t}$

This model was applied to theoretical warming rates of $2 \times 10^{6}$ and $1 \times 10^{7}{ }^{\circ} \mathrm{C} / \mathrm{min}$, corresponding to laser pulse durations of $\sim 5 \mathrm{msec}$ and $1 \mathrm{msec}$, respectively. Some 13,000 time steps were used for each analysis. Fig. 7A shows the oocyte response for the warming rate of $2 \times 10^{6}$ and $7 \mathrm{~B}$ the response for the warming rate of $1 \times 10^{7}{ }^{\circ} \mathrm{C} / \mathrm{min}$. The four curves in each figure depict the temperature-time relationships for the applied warming ramp, the surface of the extended oocyte, the half-mass radius, and the center of the oocyte. The halfmass radius is that radius at which half the oocyte mass is outside and half inside. We consider three aspects of these curves: How much does the temperature of the oocyte lag the temperature of the applied thermal ramp? How great a temperature gradient is there across the oocyte? And most importantly, is the warming rate of the oocyte different in different regions of the cell between -100 and $-30{ }^{\circ} \mathrm{C}$, the region where recrystallization of intracellular ice can occur. 
In Fig. 7 we see that thermal lags between the oocyte and the medium and between regions in the oocyte do arise but they do so well below $100^{\circ} \mathrm{C}$ and remain nearly constant over the temperature range of interest. Not surprisingly, they are greater when the warming rate is $1 \times$ $10^{7}{ }^{\circ} \mathrm{C} / \mathrm{min}$ than when it is $2 \times 10^{6}{ }^{\circ} \mathrm{C} / \mathrm{min}$. Within the oocyte, the temperature lag between the surface of the oocyte and its center is four degrees Celsius with a warming rate of $2 \times$ $10^{6}{ }^{\circ} \mathrm{C} / \mathrm{min}$ and twenty degrees with a rate of $1 \times 10^{7}{ }^{\circ} \mathrm{C} / \mathrm{min}$. While a gradient of $20^{\circ}$ might produce mechanical damage, that appears not to be the case here, for Fig. 1 shows several examples where that ultra-high warming rate yields survivals above $90 \%$.

Of greater importance is the actual warming rate the oocytes experience. When the applied rate is $2 \times 10^{6}{ }^{\circ} \mathrm{C} / \mathrm{min}$, the warming rate in all regions of the oocyte is the same (Fig. 7A). However, when the applied rate is $1 \times 10^{7}{ }^{\circ} \mathrm{C} / \mathrm{min}$ (Fig. 7B), the warming rate at oocyte half mass radius is $15 \%$ less between -100 and $-40{ }^{\circ} \mathrm{C}$ and $25 \%$ less between -100 and $-30^{\circ} \mathrm{C}$. Thus, it is less- but only 15 to $25 \%$ less.

One assumption in this modeling is that shell III extends $47.5 \mu \mathrm{m}$ from the center of the oocyte to the outer surface of the zona pellucida in isotonic media. However, as pointed out in paragraph $(d)$ of the Discussion, we have calculated that just before the initiation of vitrification, the volume of water in the oocytes in most of the $0.3 \times$ solutions we used has decreased osmotically to $\sim 13 \%$ of its isotonic value $\left(\mathrm{V}_{\mathrm{w}}=\right.$ isotonic osmolality/osmolality of the vitrification solution—see Table 1]. As a result, the volume of the cell, $\mathrm{V}_{\mathrm{c}}$, has decreased to $29 \%$ of the isotonic value $\left[\mathrm{V}_{\mathrm{c}}=\left(\mathrm{V}_{\mathrm{w}}+\mathrm{d}\right) / 1+\mathrm{d}\right)$, where $\mathrm{d}$ is the volume of the endogenous cell solids divided by the volume of water in the isotonic cell, and has a value of 0.22 in the mouse oocyte [22]. The volume of the shrunken oocyte is thus $29 \%$ of the isotonic cell volume of $221,000 \mu^{3}$ which corresponds to a radius of $25 \mu \mathrm{m}$. That is close to the half mass radius of $29.8 \mu \mathrm{m}$. Furthermore, the slope (WR) of the half-mass curve is nearly indistinguishable from the warming slopes of the two other oocyte regions plotted, even with the highest laser-induced warming rate of $1 \times 10^{7}{ }^{\circ} \mathrm{C} / \mathrm{min}$.

We note, parenthetically, that a number of investigators have attempted to warm frozen living tissues rapidly by microwave heating. Their efforts have been mostly stymied, however, by two facts. One is that water and ice have different microwave absorptivities. The other problem is that the microwave power is far from uniform in the chamber or cavity. The consequence is that one can have thermal runaways; i.e., situations where the water in a portion of the sample boils while other portions are still frozen. These problems do not arise in laser IR heating.

\section{The effects of warming vs. melting on the computation of the warming rate of the oocytes}

Consider an idealized sample of pure ice with a melting point of $-3.5^{\circ} \mathrm{C}$. The laser pulse has to warm the sample from $-180^{\circ} \mathrm{C}$ to $-3.5^{\circ} \mathrm{C}$ (frozen) and then melt the sample isothermally at $-3.5^{\circ} \mathrm{C}$. In the first portion, all the absorbed laser energy goes to warm the ice and zero goes to melt it. The second portion is the reverse. All the energy goes to melt the ice and zero energy goes to warm it. Experimentally, we have had to define $\Delta t$ as the time between initiating the laser pulse and the time the sample is melted. But as shown 
earlier, the laser energies for these two processes are about equal. Consequently, the times have to be approximately equal, and the $\Delta t$ applicable to the first portion is half of that we used in our equation. If $\Delta t$ is halved, then the actual warming rates are twice those that we have calculated by $\mathrm{WR}=\Delta \mathrm{T} / \Delta \mathrm{t}$. In practice the error is not this large because the sample is an aqueous solution of EAFS and not pure ice. Above the eutectic point of $\sim-60^{\circ} \mathrm{C}$, the laser energy begins both to warm the sample and to simultaneously melt it. As more and more of the absorbed energy is diverted to the melting of ice, the more the warming rate is slowed. This slowing of the warming somewhat compensates for the 2-fold increase in warming rate that we discussed in the previous paragraph. A more detailed analysis of these complexities will require a more comprehensive finite element model, the development of which is currently in progress.

Summarizing the above, the true warming rates over our range of interest are almost certainly higher than those we calculated from the simple formula $\mathrm{WR}=\Delta \mathrm{T} / \Delta \mathrm{t}$, but they are probably less than twice as high because of the behavior of solutions during warming. At an uncorrected laser ramp warming rate of $1 \times 10^{7}{ }^{\circ} \mathrm{C} / \mathrm{min}$, the oocytes warm about $25 \%$ more slowly; namely, $0.75 \times 10^{7 \circ} \mathrm{C} / \mathrm{min}$. However, there are no differences in warming rate within the oocyte. At an uncorrected warming rate of $2 \times 10^{6}{ }^{\circ} \mathrm{C} / \mathrm{min}$, no differences in warming rates are detectable among any of the curves.

\section{The Cryo-Jig}

Figure 3 is a photograph of the Jig in a pre sample loading configuration. After XYZ positioning in the laser chamber (Fig. 2), the Cryotop tip and sample are held under $\mathrm{LN}_{2}$. Then the left end of the Cryotop holder [3] is pressed manually, tipping the sample out of the $\mathrm{LN}_{2}$ in the Styrofoam well, releasing the $\mathrm{LN}_{2}$ cover slide to cover the well, and firing the laser as the slide slips into position. The operational details are as follows: $\mathrm{The}^{\mathrm{LN}} \mathrm{N}_{2}$ well [5] in the Styrofoam block is filled with $\mathrm{LN}_{2}$. Then,

i. The cover slide [6] is then moved left to isolate the blade of the Cryotop from the $\mathrm{LN}_{2}$.

ii. The handle of an unloaded Cryotop [2] is placed in the wooden block holder [3] in a horizontal position. In this position, the entire blade portion of the Cryotop and part of its handle are separated from the $\mathrm{LN}_{2}$ and $\mathrm{LN}_{2}$ vapor in the well by the cover slide.

iii. By manually sliding the Jig, the tip of the Cryotop blade where the sample is to be located [1] is positioned in $\mathrm{XY}$ at the location where the laser beam will strike. This positioning is achieved by use of cross hairs in the stereomicroscope built into the laser. This ensures that the $2 \mathrm{~mm}$ diameter laser beam will strike the sample. From this point on, the Jig can not be moved.

iv. In parallel with iii, some five oocytes have been transferred from the PB1

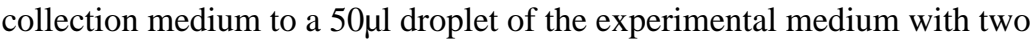
washings intervening. At $1.5 \mathrm{~min}$ after the initial exposure to that medium, a $0.1 \mu \mathrm{l}$ droplet of the test solution containing five oocytes or 2-cell embryos is placed on 
the tip of the Cryotop blade. The $\mathrm{Z}$ position is held constant by a shim of appropriate thickness under the Jig.

v. At $2.0 \mathrm{~min}$ after the initial exposure of the oocytes or 2-cell embryos to the test solution, the cover slide [6] is moved fully to the right to fully expose the $\mathrm{LN}_{2}$ in the well [5], and the holding block [3] is rotated manually to immerse the blade of the Cryotop into the $\mathrm{LN}_{2}$. The $2.0 \mathrm{~min}$ is the exposure time that Pedro [21] found to yield the best survivals of ICR oocytes after vitrification. This relatively short time also reduces evaporation of the droplet prior to cooling [26].

vi. To initiate warming, the left side of the holder block [3] is pressed down with a finger to lift the Cryotop and sample out of the $\mathrm{LN}_{2}$ reservoir and into a horizontal position. This depresses the trigger tab [8 right] which releases the $\mathrm{LN}_{2}$ cover tab [8 left] which allows the cover slide [6] to be pulled to the left, covering the reservoir. When the cover slide slips into position, it hits the contact switch [9] which fires the laser. This entire operation in vii) is completed in $<0.25 \mathrm{~s}$. 


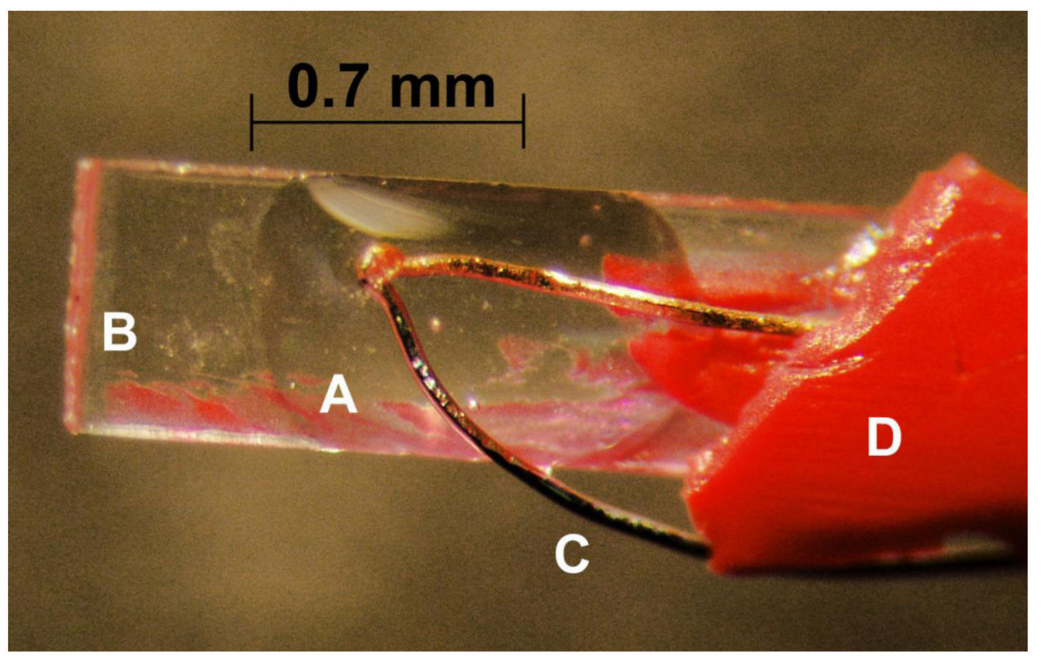

Fig. 1.

Cryotop blade (B) equipped with a $50 \mu \mathrm{m}$ copper-constantan thermocouple (C). The junction of the thermocouple is immersed in a $0.1 \mu \mathrm{l}$ droplet of the test medium (A). The thermocouple is held in place by a small dab of nail polish (D). Slightly modified from [11] by permission of Elsevier. 


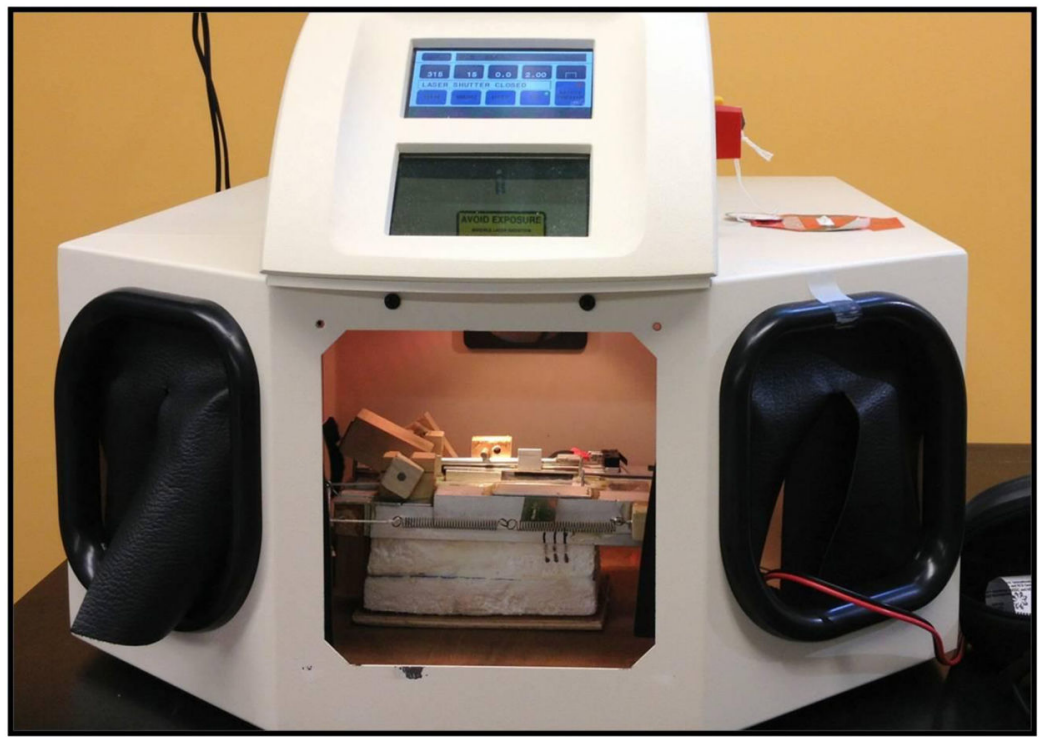

Fig. 2.

The Laser Star laser with the Cryo Jig positioned in its working chamber. The laser beam is oriented vertically. 


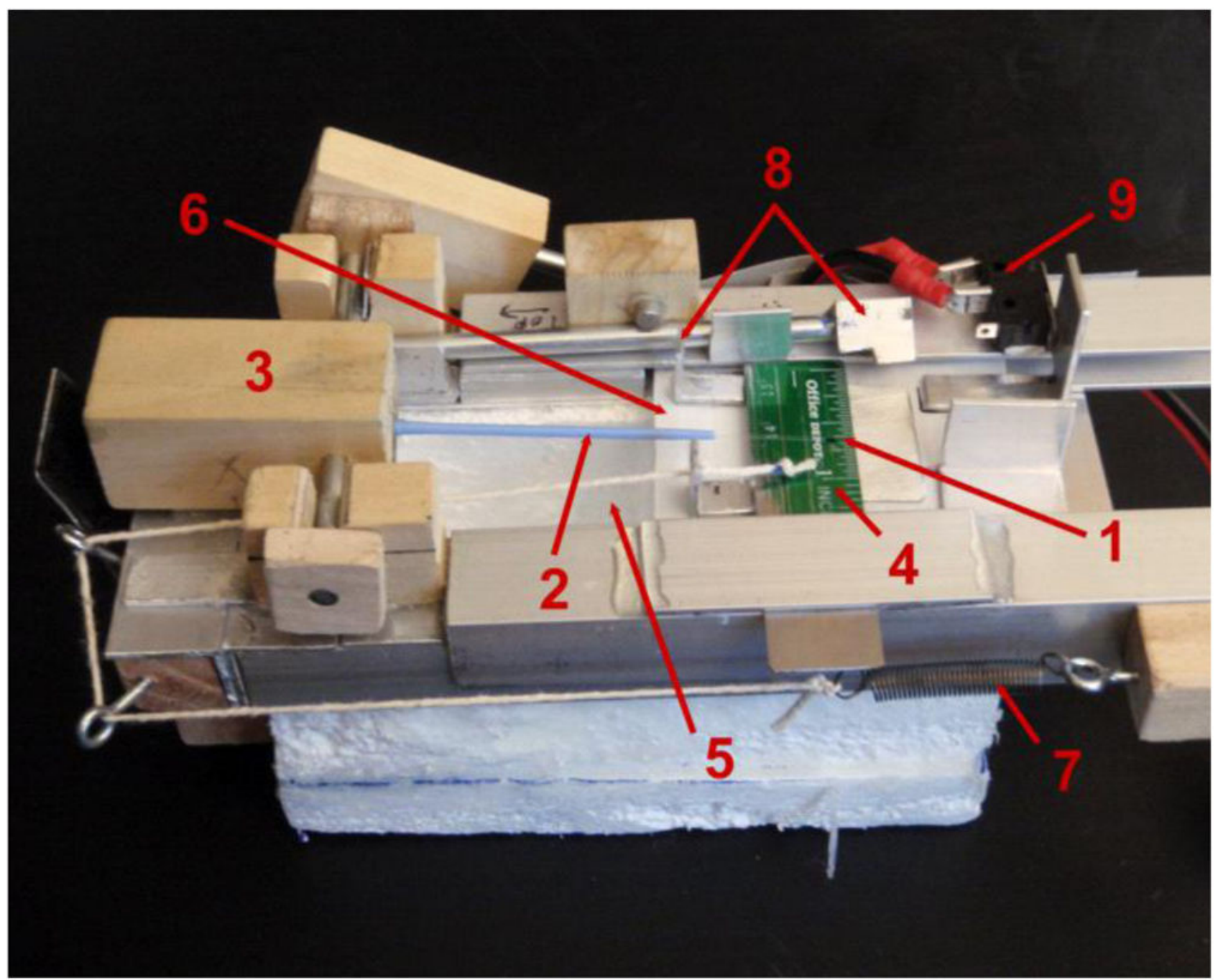

Fig. 3.

The Cryo Jig used to manipulate the Cryotop during rapid cooling in $\mathrm{LN}_{2}$ or $\mathrm{LN}_{2}$ vapor and ultra-rapid warming by a laser pulse.

The components are:

1. Tip of Cryotop where sample is placed.

2. Cryotop.

3. Cryotop holder (which pivots on shaft through block).

4. Ruler (removable) to align the Jig and sample under the laser.

5. Styrofoam $\mathrm{LN}_{2}$ reservoir.

6. $\mathrm{LN}_{2}$ cover slide to protect sample from being cooled by cold nitrogen vapor cooling after completion of the laser pulse.

7. Spring to pull $\mathrm{LN}_{2}$ cover slide into place. 
8. Cover slide tab (left) and trigger tab (right) to hold (up position) and then release (down position) cover slide.

9. Contact switch which fires the laser when the cover slide slips into place.

The distance from the left to the right side of the Styrofoam base is $13 \mathrm{~cm}$. 


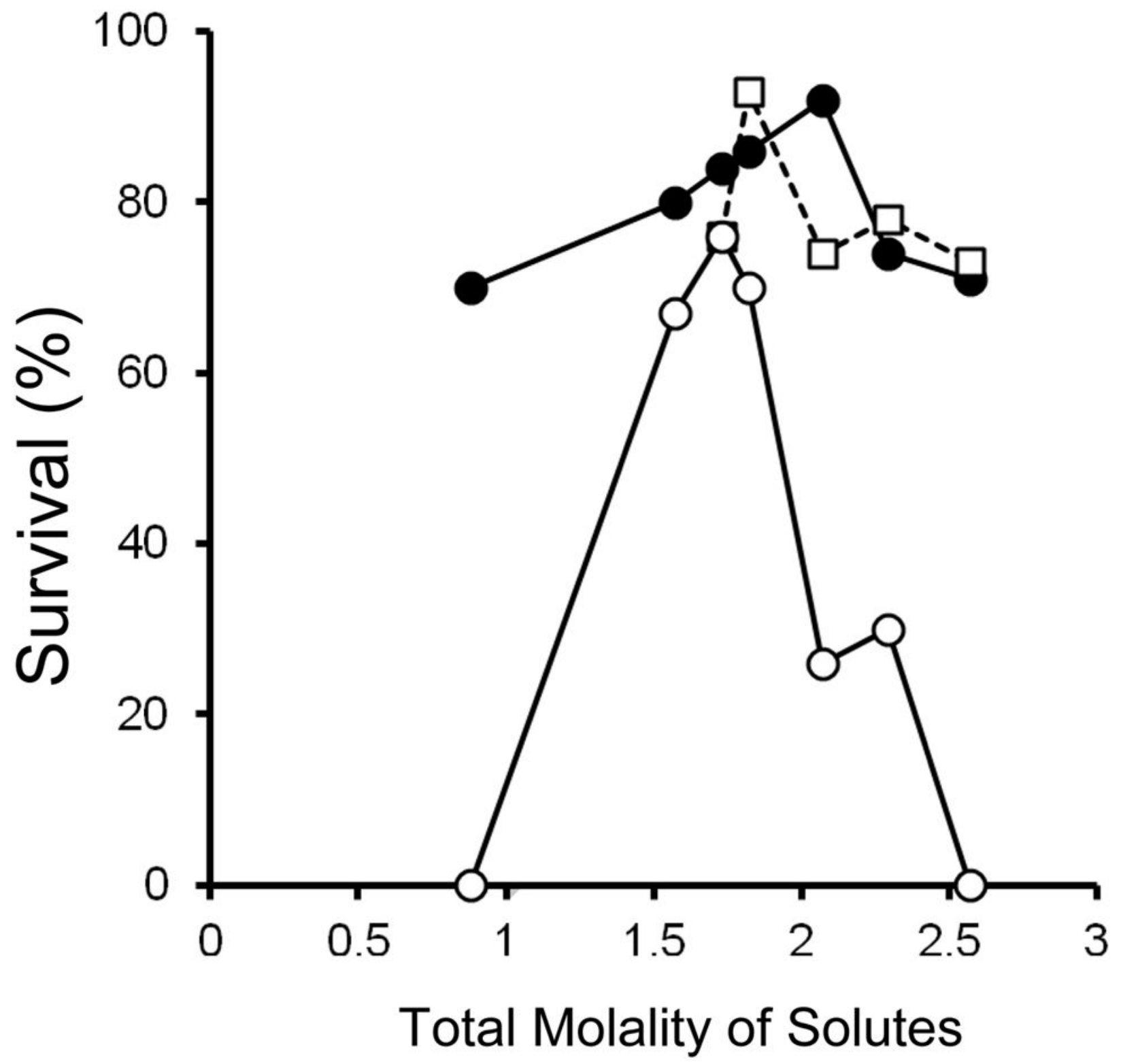

Fig. 4.

Osmotic/morphological survival of mouse ICR oocytes as a function of the total molality of solutes in the modified EAFS solutions in which they were suspended during cooling at $69,000^{\circ} \mathrm{C} / \mathrm{min}$ and warming at $1.0 \times 10^{7}{ }^{\circ} \mathrm{C} / \mathrm{min}(\mathbf{O}), 3.0 \times 10^{6}{ }^{\circ} \mathrm{C} / \mathrm{min}(\boldsymbol{\square})$, and $1.2 \times 10^{5}$ ${ }^{\circ} \mathrm{C} / \mathrm{min}(\bigcirc)$. The two highest rates were achieved by applications of laser pulses. The solutions used to generate the seven data points in $\bigcirc$ and $\bigcirc$ (from left to right) are Numbers $11,10,9,8,7,5$, and 6 , in Table 1 . 


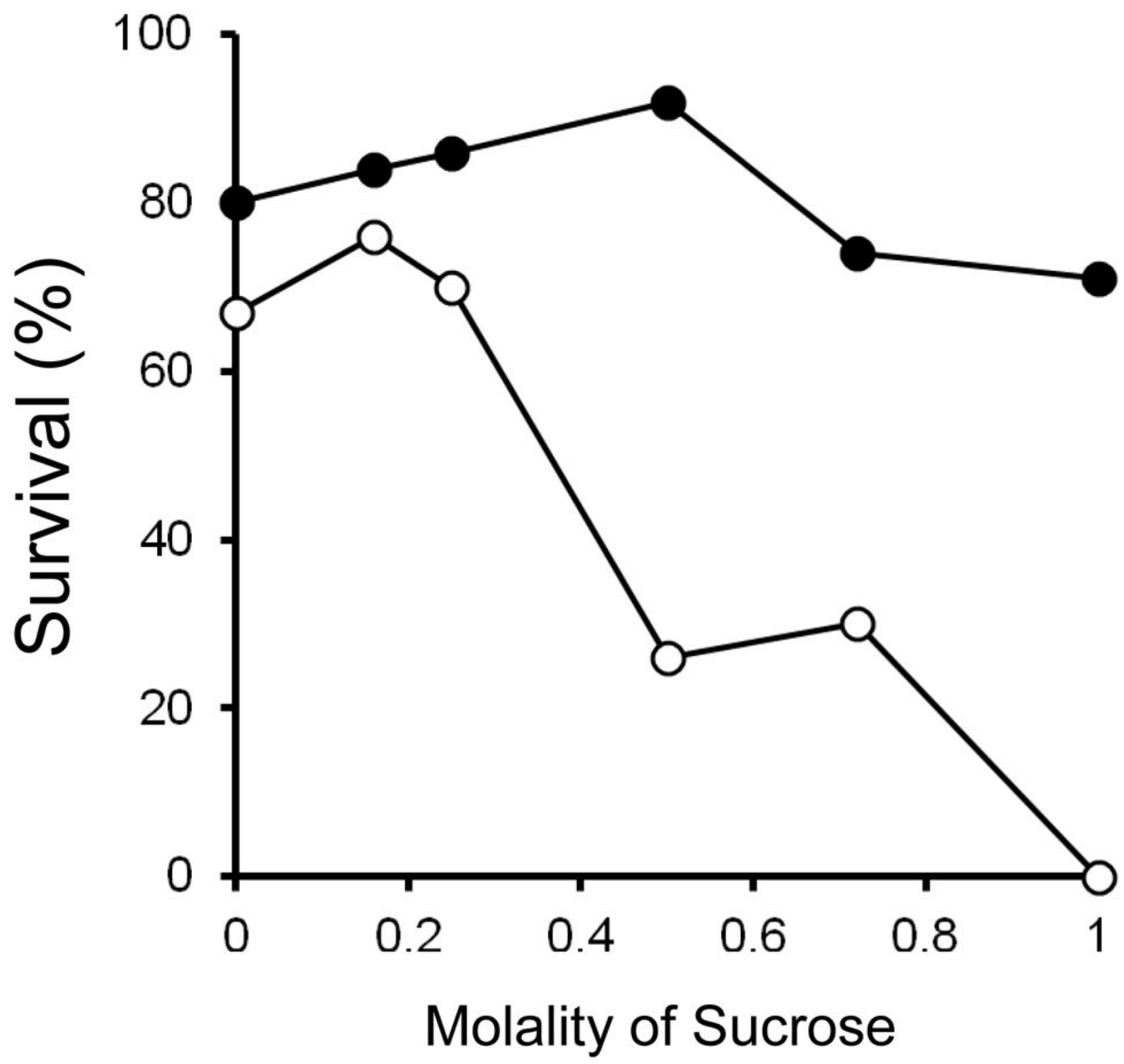

Fig. 5.

Survival of mouse oocytes subjected to very rapid cooling and laser assisted ultra-rapid warming as a function of the molality of sucrose in the external solutions. Reading from left to right, the six solutions were Numbers $10,9,8,7,5$, and 6 in Table 1 . The closed circles give the survivals when the warming was laser-accelerated to produce a rate of $1.0 \times 10^{7}{ }^{\circ} \mathrm{C} /$ $\min$. The open circles give the survivals when the samples were not exposed to the laser, and the rate was $1.2 \times 10^{5}{ }^{\circ} \mathrm{C} / \mathrm{min}$-about 100 -fold slower. 


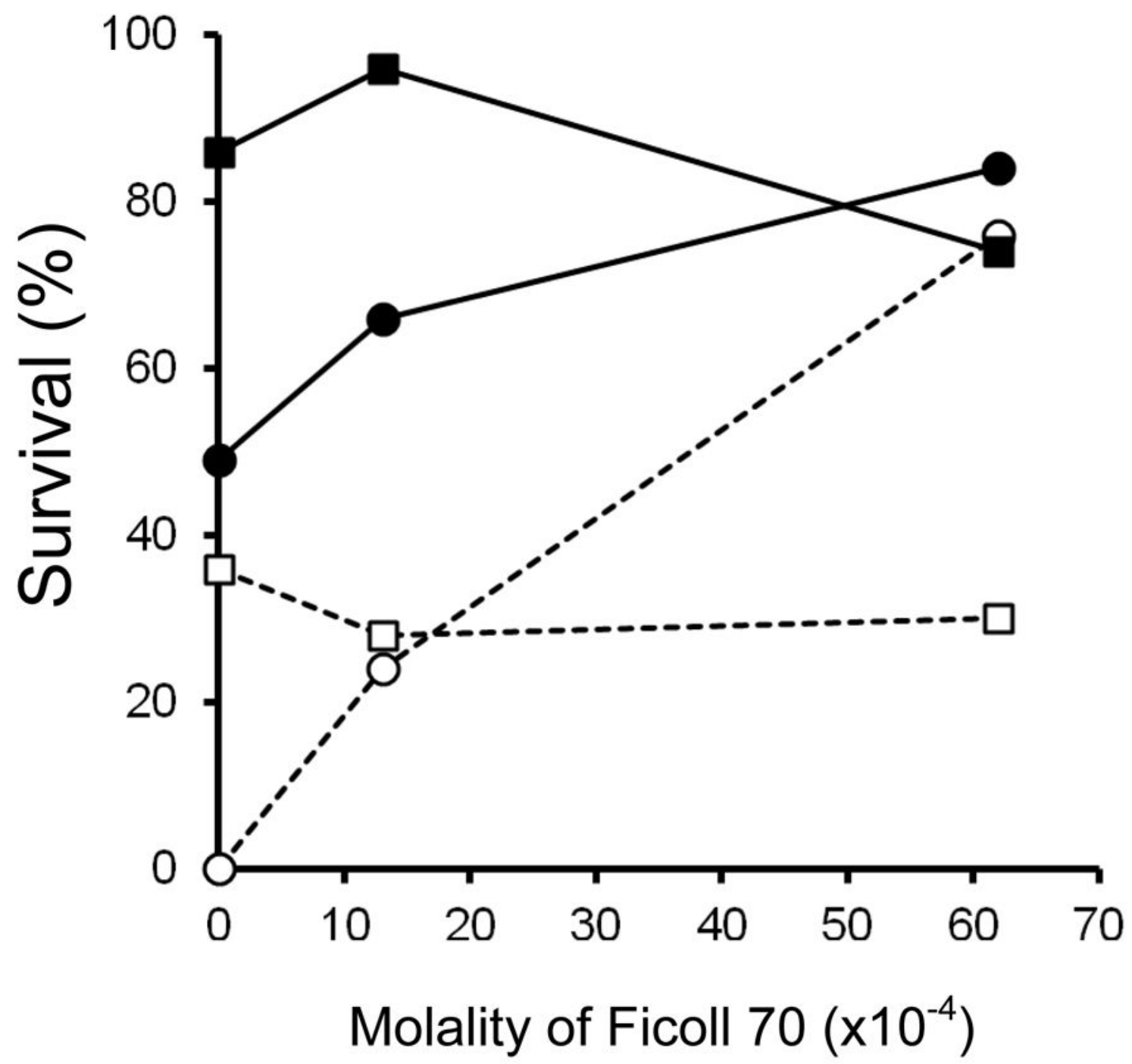

Fig. 6.

Osmotic/morphological survival of mouse ICR oocytes as a function of the molality of Ficoll 70 and two concentrations of sucrose in the modified EAFS solutions in which they were suspended during cooling at $69,000^{\circ} \mathrm{C} / \mathrm{min}$ and warming at either $1.0 \times 10^{7} \mathrm{C} / \mathrm{min}$ by laser (closed symbols) or at $1.2 \times 10^{5}{ }^{\circ} \mathrm{C} / \mathrm{min}$ without the laser (open symbols). The sucrose molalities were 0.16 molal (circles) or 0.72 molal (squares). Their full compositions are those of solutions 1, 2, 9 and 3, 4, 5 in Table 1. 

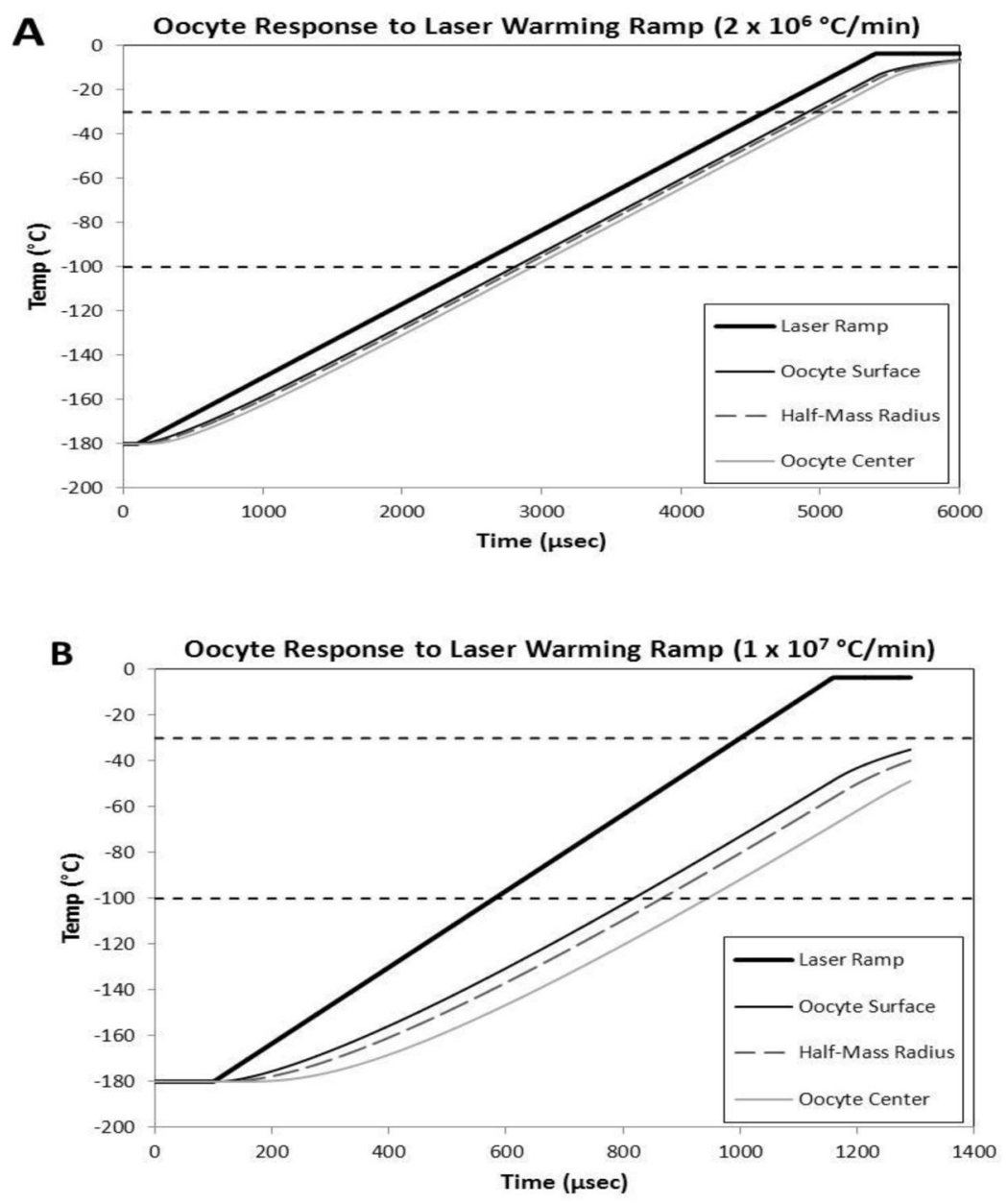

Fig. 7.

Thermal response of oocytes when subjected to laser-induced warming rates of $2 \times 10^{6}$ ${ }^{\circ} \mathrm{C} / \mathrm{min}$ (panel A) and $1 \times 10^{7}{ }^{\circ} \mathrm{C} / \mathrm{min}$ (panel B) determined using finite element analysis. Both panels contain 4 curves: The top bold curve is the applied warming ramp; i.e., the laser-driven temperature of the EAFS solution plus India Ink surrounding the oocyte. The remaining three curves show the response temperature at the surface of the oocyte proper (at $r=37.5 \mu \mathrm{m})$, at the half mass radius $(r=29.8 \mu \mathrm{m})$, and at the center of the oocyte $(r=0)$. At an applied warming rate (WR) of $2 \times 10^{6}{ }^{\circ} \mathrm{C} / \mathrm{min}$ (panel A), the oocyte lags the applied ramp slightly but the slope (WR) of the oocyte is the same as the applied rate. However, at a WR of $1 \times 10^{7} \mathrm{C} / \mathrm{min}$ (panel B), the oocyte temperature lags, and the response WR (slope) of the oocyte is slightly less $\left(0.75 \times 10^{7}{ }^{\circ} \mathrm{C} / \mathrm{min}\right.$ between $-100^{\circ} \mathrm{C}$ and $\left.-30^{\circ} \mathrm{C}\right)$ than the applied rate of $1.0 \times 10^{7 \circ} \mathrm{C} / \mathrm{min}$. 


\begin{tabular}{|c|c|c|c|c|c|c|c|c|c|c|c|c|c|c|}
\hline 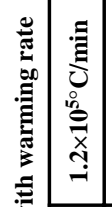 & 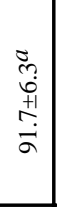 & 0 & \begin{tabular}{c}
0 \\
$\dot{j}$ \\
+1 \\
+ \\
\multirow{v}{*}{}
\end{tabular} & 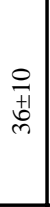 & $\mid \begin{array}{c}0 \\
0 \\
o \\
0 \\
01 \\
\sim\end{array}$ & 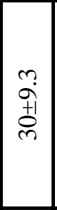 & 0 & 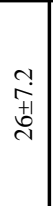 & $\mid$\begin{tabular}{|c}
$n$ \\
0 \\
0 \\
$\vdots 1$ \\
2 \\
\end{tabular} & $\begin{array}{l}n \\
i \\
+1 \\
0 \\
0\end{array}$ & $\mid \begin{array}{c}0 \\
0 \\
o \\
+1 \\
0 \\
\delta\end{array}$ & 0 & 0 & 0 \\
\hline 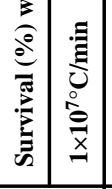 & ' & $\begin{array}{l}a \\
0 \\
0 \\
⿱ 1 \\
\sigma\end{array} \mid$ & $\mid \begin{array}{l}0 \\
0 \\
0 \\
01 \\
0\end{array}$ & 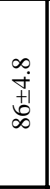 & $\mid$\begin{tabular}{r}
$\hat{i}$ \\
$i$ \\
\multirow{1}{0}{}
\end{tabular} & \begin{tabular}{|l}
$\infty$ \\
$\dot{0}$ \\
$\dot{0}$ \\
\multirow{1}{*}{}
\end{tabular} & $\begin{array}{c}2 \\
i+1 \\
\stackrel{+1}{r}\end{array}$ & $\begin{array}{l}3 \\
\dot{\jmath} \\
\Delta \\
\Omega\end{array}$ & $\mid \begin{array}{l}0 \\
+ \\
+1 \\
\infty\end{array}$ & $\begin{array}{c}n \\
+ \\
+1 \\
+ \\
+\end{array}$ & $\mid \begin{array}{l}\infty \\
0 \\
+1 \\
0 \\
\infty\end{array}$ & $\begin{array}{l}\hat{0} \\
\dot{1} \\
\stackrel{1}{2}\end{array}$ & $\begin{array}{l}n \\
\sim \\
+\uparrow \\
+ \\
\infty\end{array}$ & $\begin{array}{l}\text { ma } \\
\text { î̀ } \\
\text { in }\end{array}$ \\
\hline 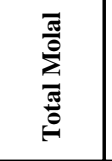 & $\stackrel{\infty}{\stackrel{\infty}{?}}$ & $\stackrel{\overbrace{}}{=}$ & $\stackrel{\sim}{\stackrel{ }{二}}$ & 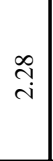 & 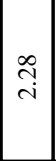 & ते & in & $\overrightarrow{\mathrm{i}}$ & $\left.\mid \begin{array}{c}0 \\
\infty \\
-\end{array}\right]$ & $\stackrel{?}{=}$ & $\underline{n}$ & $\begin{array}{l}\infty \\
\infty \\
0 \\
0\end{array}$ & $\mid \begin{array}{l}0 \\
\infty \\
0 \\
0\end{array}$ & $\stackrel{\substack{\infty \\
\infty}}{\infty}$ \\
\hline $\begin{array}{l}\overline{\overline{0}} \\
\frac{0}{5} \\
\overline{\bar{s}} \\
\frac{0}{2}\end{array}$ & 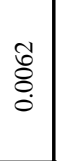 & 0 & $\begin{array}{l}m \\
0 \\
0 \\
0\end{array}$ & $\circ$ & $\mid \begin{array}{l}m \\
0 \\
0 \\
0\end{array}$ & 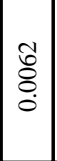 & 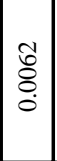 & 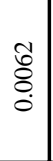 & $\mid \begin{array}{l}0 \\
ٌ \\
0 \\
0\end{array}$ & $\begin{array}{l}\tilde{\delta} \\
\vdots \\
0 \\
0\end{array}$ & 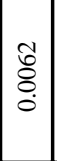 & $\begin{array}{l}0 \\
\stackrel{0}{0} \\
0\end{array}$ & $\mid \begin{array}{l}m \\
\\
0 \\
0\end{array}$ & 0 \\
\hline 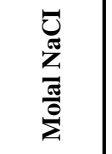 & $\frac{n}{0}$ & $\stackrel{0}{0}$ & $\stackrel{2}{0}$ & $\frac{n}{0}$ & $\frac{n}{0}$ & $\stackrel{n}{0}$ & $\stackrel{n}{0}$ & $\stackrel{0}{0}$ & $\stackrel{n}{0}$ & $\frac{n}{0}$ & $\stackrel{n}{0}$ & $\stackrel{\circ}{0}$ & $\stackrel{n}{0}$ & $\stackrel{n}{0}$ \\
\hline 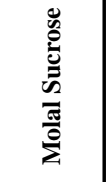 & $\stackrel{\mathbb{0}}{0}$ & $\stackrel{0}{0}$ & $\stackrel{0}{\circ}$ & 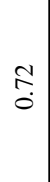 & 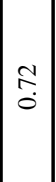 & $\frac{0}{0}$ & $\stackrel{8}{-}$ & in & $\begin{array}{l}\text { व̃ } \\
0\end{array}$ & $\frac{0}{0}$ & 0 & $\stackrel{\overbrace{}}{0}$ & 尺̂. & $\stackrel{\overbrace{}}{0}$ \\
\hline 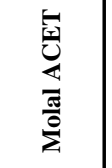 & సે & $\stackrel{\overrightarrow{0}}{0}$ & $\vec{i}$ & $\stackrel{\overrightarrow{0}}{0}$ & $\mid \begin{array}{l}\overrightarrow{0} \\
0\end{array}$ & $\vec{i}$ & $\vec{i}$ & $\vec{i}$ & $\stackrel{i}{0}$ & $\overrightarrow{0}$ & $\mid \begin{array}{l}\overrightarrow{0} \\
0\end{array}$ & 0 & 0 & 0 \\
\hline 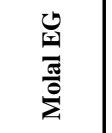 & $\underset{\overbrace{}}{\pi}$ & $\begin{array}{l}R \\
0\end{array}$ & $\begin{array}{l}R \\
0 \\
0\end{array} \mid$ & $\begin{array}{l}R \\
0\end{array}$ & $\begin{array}{l}? \\
0 \\
0\end{array}$ & $\begin{array}{l}R \\
0 \\
0\end{array}$ & $\stackrel{R}{0}$ & $\begin{array}{l}R \\
0\end{array}$ & $\begin{array}{l}R \\
0\end{array}$ & $\begin{array}{l}R \\
0 \\
0\end{array}$ & $\begin{array}{l}R \\
0 \\
0\end{array}$ & 0 & 0 & 0 \\
\hline 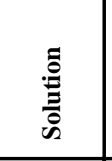 & $\begin{array}{l}\overrightarrow{\vec{v}} \\
\underline{x}\end{array}$ & 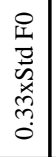 & 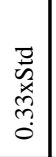 & $\begin{array}{l}0 \\
0 \\
\overline{1} \\
\tilde{m} \\
\tilde{n} \\
0\end{array}$ & 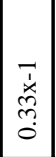 & 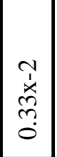 & 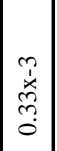 & $\begin{array}{l}+ \\
\dot{x} \\
\infty \\
\tilde{\sigma} \\
0\end{array}$ & $\mid \begin{array}{c}n \\
\tilde{x} \\
\tilde{x} \\
\tilde{c} \\
0\end{array}$ & 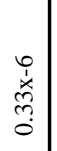 & 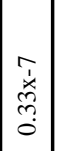 & 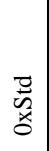 & 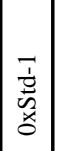 & 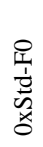 \\
\hline$\dot{z}$ & & - & $\sim$ & $m$ & $\nabla$ & in & 0 & $r$ & $\infty$ & $a$ & $\circ$ & $=$ & $\simeq$ & 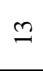 \\
\hline
\end{tabular}




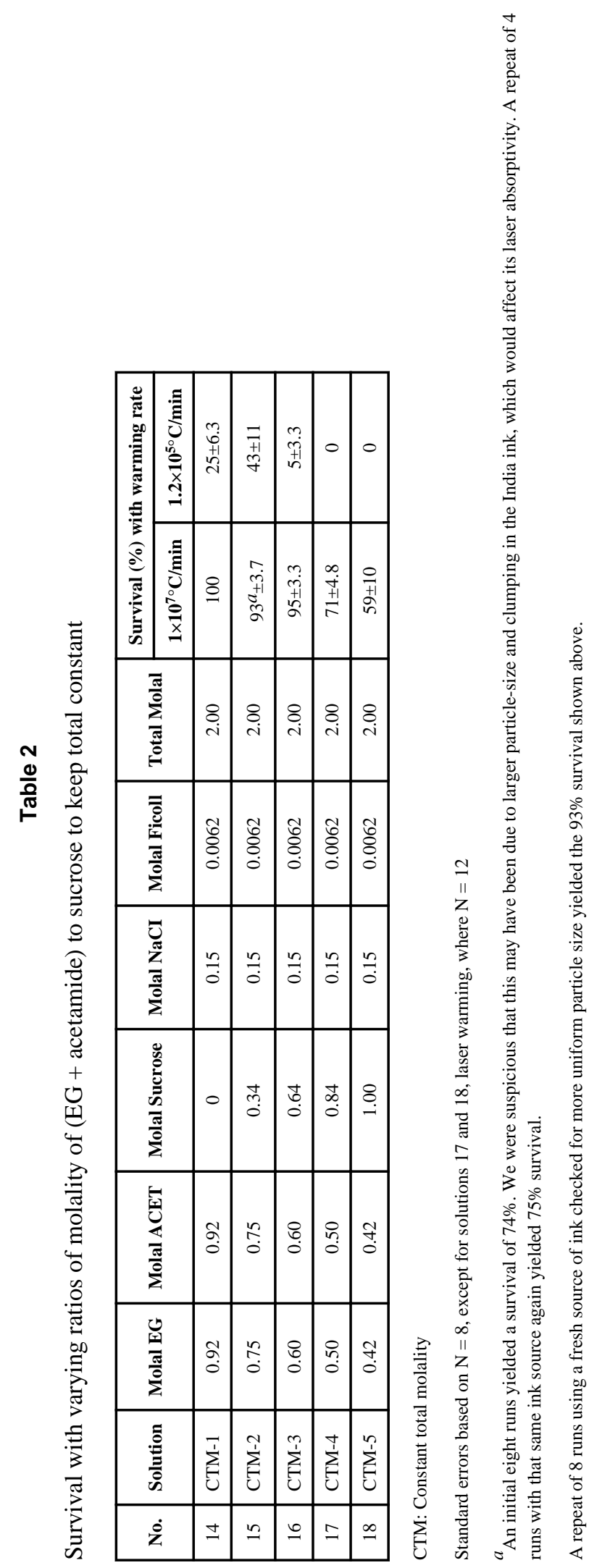

Cryobiology. Author manuscript; available in PMC 2015 June 01. 
Table 3

Functional survival of fresh and vitrified mouse oocytes and 2-cell embryos

\begin{tabular}{|l|c|c|c|c|}
\hline Vitrification sol'n & \# eggs/2-cell embryos (\# runs) & $\mathbf{N}(\%)$ Morpholog. Normal & $\mathbf{N}(\%)$ 2-cell & N (\%) Expanded Blastocyst \\
\hline A. Oocytes ${ }^{a}$ & & & & \\
\hline None (Control) & $40(8)$ & $40(100)$ & $38(95 \pm 3.3)$ & $32(80 \pm 3.8)$ \\
\hline $0.33-4^{b}$ & $40(8)$ & $36(90 \pm 4.0)$ & $30(83 \pm 6.1)$ & $20(56 \pm 4.9)$ \\
\hline $0.33-5^{b}$ & $25(5)$ & $22(88 \pm 4.9)$ & $19(86 \pm 8.0)$ & $11(50 \pm 6.4)$ \\
\hline B, 2-cell embryos & & & & \\
\hline None (Control) & $20(4)$ & $20(100)$ & - & $16(80 \pm 11.5)$ \\
\hline Solution control & $20(4)$ & $20(100)$ & - & $17(85 \pm 9.6)$ \\
\hline $0.33-4^{b}$ & $25(5)$ & $23(92 \pm 4.9)$ & - & $20(88 \pm 8.0)$ \\
\hline
\end{tabular}

The number and percentage that are morphologically normal is Columns $3 / 2$. The numbers and percentages that are functionally viable are Columns $4 / 3$ and $5 / 3$

${ }^{a}$ After vitrification, the oocytes were exposed to freshly collected sperm diluted to a concentration of $3 \times 10^{6} / \mathrm{ml}$ with Cook Fertilization medium. The sperm concentration is critical (see text)

${ }^{b}$ These two solutions yielded about the highest morphological survivals after vitrification of those tried. They are both modified 3-fold dilutions of standard full strength EAFS-10-10 vitrification solution with the compositions given in Table 1. The oocytes in those solutions were cooled to $-196^{\circ} \mathrm{C}$ at $\sim 69,000^{\circ} \mathrm{C} / \mathrm{min}$ and warmed by laser at an estimated $1.0 \times 10^{7}{ }^{\circ} \mathrm{C} / \mathrm{min}$. Samples of 2-cell embryos were also warmed 100 -times more slowly at $10^{5}{ }^{\circ} \mathrm{C} / \mathrm{min}$. Only $5 \%$ were morphologically normal and $0 / 20$ developed to expanded blastocysts.

${ }^{c}$ Fresh 2-cell embryos collected from the oviducts of mated females. 
Table 4

Bearing of our experiments on current orthodox views on vitrification

\begin{tabular}{|l|l|l|}
\hline Item & Orthodox view & Our findings \\
\hline $\begin{array}{l}\text { Solute concentration in vitrification } \\
\text { solution (VS) }\end{array}$ & VS needs to be 6 molal or higher & 1.8 molal VS yields up to $92 \%$ survival \\
\hline Permeation of VS solutes & Essential & Not required-may be detrimental \\
\hline Cooling rate requirements & Very high $\left(>40,000^{\circ} \mathrm{C} / \mathrm{min}\right)$ & $\begin{array}{l}\text { Can be as low as } 10,000^{\circ} \mathrm{C} / \mathrm{min}, \text { and perhaps } \\
\text { lower }\end{array}$ \\
\hline Warming rate requirements & $\begin{array}{l}\text { High rates assumed to be important but no } \\
\text { experimental data }\end{array}$ & $\begin{array}{l}\text { Ultra-high rates }\left(10^{7{ }^{\circ}} \mathrm{C} / \mathrm{min}\right) \text { are critical to high } \\
\text { survivals }\end{array}$ \\
\hline
\end{tabular}

